OPEN ACCESS

Edited by:

Akihiko Yamagishi,

Tokyo University of Pharmacy and Life

Sciences, Japan

Reviewed by:

Susan Childers,

Colby College, United States

Juliane Hopf

University of Notre Dame,

United States

*Correspondence:

Scott D. Hamilton-Brehm

Scott.Hamilton-Brehm@siu.edu

Duane P. Moser

Duane.Moser@dri.edu

Specialty section:

This article was submitted to

Microbiological Chemistry

and Geomicrobiology,

a section of the journal

Frontiers in Microbiology

Received: 04 June 2019 Accepted: 11 September 2019 Published: 27 September 2019

Citation:

Hamilton-Brehm SD, Stewart LE, Zavarin M, Caldwell M, Lawson PA,

Onstott TC, Grzymski J, Neveux I,

Lollar BS, Russell CE and Moser DP

(2019) Thermoanaerosceptrum

fracticalcis gen. nov. sp. nov., a Novel Fumarate-Fermenting Microorganism

From a Deep Fractured Carbonate

Aquifer of the US Great Basin.

Front. Microbiol. 10:2224.

doi: 10.3389/fmicb.2019.02224

\section{Thermoanaerosceptrum fracticalcis} gen. nov. sp. nov., a Novel Fumarate-Fermenting Microorganism From a Deep Fractured Carbonate Aquifer of the US Great Basin

\author{
Scott D. Hamilton-Brehm ${ }^{1,2 *}$, Laura E. Stewart ${ }^{3}$, Mavrik Zavarin 4 , Matt Caldwell ${ }^{5}$, \\ Paul A. Lawson ${ }^{5}$, Tullis C. Onstott 6 , Joseph Grzymski ${ }^{1}$, Iva Neveux', \\ Barbara Sherwood Lollar ${ }^{7}$, Charles E. Russell ${ }^{3}$ and Duane P. Moser ${ }^{1,8 *}$
}

${ }^{1}$ Division of Earth and Ecosystems Sciences, Desert Research Institute, Las Vegas, NV, United States, ${ }^{2}$ Department of Microbiology, Southern Illinois University Carbondale, Carbondale, IL. United States, ${ }^{3}$ Madison Area Technical College, Madison, WI, United States, ${ }^{4}$ Lawrence Livermore National Laboratory, Livermore, CA, United States, ${ }^{5}$ Department of Microbiology and Plant Biology, University of Oklahoma, Norman, OK, United States, ${ }^{6}$ Department of Geosciences, Princeton University, Princeton, NJ, United States, ${ }^{7}$ Department of Earth Sciences, University of Toronto, Toronto, ON, Canada, ${ }^{8}$ Division of Hydrologic Sciences, Desert Research Institute, Las Vegas, NV, United States

Deep fractured rock ecosystems across most of North America have not been studied extensively. However, the US Great Basin, in particular the Nevada National Security Site (NNSS, formerly the Nevada Test Site), has hosted a number of influential subsurface investigations over the years. This investigation focuses on resident microbiota recovered from a hydrogeologically confined aquifer in fractured Paleozoic carbonate rocks at 863 - 923 meters below land surface. Analysis of the microorganisms living in this oligotrophic environment provides a perspective into microbial metabolic strategies required to endure prolonged hydrogeological isolation deep underground. Here we present a microbiological and physicochemical characterization of a deep continental carbonate ecosystem and describe a bacterial genus isolated from the ecosystem. Strain DRI-13 ${ }^{\top}$ is a strictly anaerobic, moderately thermophilic, fumarate-respiring member of the phylum Firmicutes. This bacterium grows optimally at $55^{\circ} \mathrm{C}$ and $\mathrm{pH}$ 8.0, can tolerate a concentration of $100 \mathrm{mM} \mathrm{NaCl}$, and appears to obligately metabolize fumarate to acetate and succinate. Culture-independent 16S rRNA gene sequencing indicates a global subsurface distribution, while the closest cultured relatives of DRI$13^{\top}$ are Pelotomaculum thermopropionicum (90.0\% similarity) and Desulfotomaculum gibsoniae $\left(88.0 \%\right.$ similarity). The predominant fatty acid profile is iso- $\mathrm{C}_{15: 0}, \mathrm{C}_{15: 0}$, $\mathrm{C}_{16: 0}$ and $\mathrm{C}_{14: 0}$. The percentage of the straight-chain fatty acid $\mathrm{C}_{15: 0}$ is a defining characteristic not present in the other closely related species. The genome is estimated to be $3,649,665 \mathrm{bp}$, composed of $87.3 \%$ coding regions with an overall average of $45.1 \% \mathrm{G}+\mathrm{C}$ content. Strain DRI-13 ${ }^{\top}$ represents a novel genus of subsurface bacterium isolated from a previously uncharacterized rock-hosted geothermal habitat. 
The characterization of the bacterium combined with the sequenced genome provides insights into metabolism strategies of the deep subsurface biosphere. Based on our characterization analysis we propose the name Thermoanaerosceptrum fracticalcis

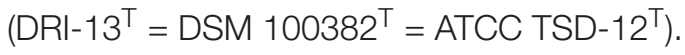

Keywords: 16S rRNA, subsurface, deep biosphere, Firmicutes, fractured carbonate, aquifer, borehole, Death Valley Regional Flow System

\section{INTRODUCTION}

Biomass in the continental crust may be greater than that on the surface of the Earth (Gold, 1992; Whitman et al., 1998; McMahon and Parnell, 2014; Magnabosco et al., 2018). The deep biosphere is an untapped reservoir of microbial biodiversity that may hold novel solutions to industrial, medical, and origin of life questions. While the concept of subsurface life was proposed in the 1920s (Bastin and Greer, 1930), research into deep terrestrial subsurface environments did not begin in earnest until the 1980s (Jorgensen, 2012). Exploration of subsurface microbial biogeochemical processes remain largely unmapped and uncharacterized, due partly to limited access to the terrestrial subsurface and the low biomass densities often found there. Primary sampling opportunities occur through caves, mines, springs, and boreholes. A high level of novel microbial diversity has been discovered in the subsurface through cultivationindependent sequencing of the 16S rRNA gene (Pedersen and Ekendahl, 1990; Kotelnikova and Pedersen, 1997; Takai et al., 2001; Chapelle et al., 2002; Moser et al., 2005; Lin et al., 2006; Osburn et al., 2014). However, only a modest fraction of known lineages are currently represented in culture collections (Daumas et al., 1988; Boone et al., 1995; Ravot et al., 1995; Nilsen et al., 1996; Puspita et al., 2012).

With some notable exceptions (Stevens and McKinley, 1995; Colwell et al., 1997; Fredrickson et al., 1997; Krumholz et al., 1997; Lehman et al., 2001; Osburn et al., 2014), the deep fractured rock ecosystems across most of North America have been relatively little studied for microbiology. However, the US Great Basin, in particular the Nevada National Security Site (NNSS, formerly the Nevada Test Site, Bowen et al., 2001), has hosted a number of influential subsurface investigations over the years (Amy et al., 1992; Haldeman and Amy, 1993; Haldeman et al., 1993; Kieft et al., 1997). Most of the NNSS lies entirely within a geologic extensional zone and is underlain by the "Death Valley Regional Flow System (DVRFS)." This expansive set of groundwater basins is dominated by fractured rock aquifers that comprises $\sim 100,000 \mathrm{~km}^{2}$ of mountain ranges (up to $3,600 \mathrm{~m}$ above mean sea level) and valleys which can reach below sea level (e.g., Death Valley, at $-86 \mathrm{~m}$, the lowest point in North America) (D'Agnese et al., 1997; Belcher et al., 2002; Ye et al., 2008; Bushmann et al., 2010). Within this system groundwater flows long distances (i.e., Interbasin Flow), from high-elevation recharge zones in central Nevada to large-discharge springs in and near Death Valley, CA, United States (Winograd and Thordarson, 1975; Winograd and Pearson, 1976; Belcher et al., 2009). Direct access to the DVRFS is achievable through an ongoing Department of Energy (DOE) sponsored environmental management activity tasked with tracking groundwater contamination associated with underground nuclear testing at the NNSS, the Underground Test Area (UGTA) sub-project. The hundreds of monitoring boreholes/wells established and maintained by this program represent a unique regional-scale observatory for deep life study.

This study focuses on resident microbiota in fluids from 863 923 meters below land surface (mbls), accessed via a monitoring borehole, U-3cn\#5 (Garber and Johnson, 1967; Bangerter and Giblin, 1998). Intercepting a hydrogeologically confined aquifer within the fractured Paleozoic carbonate rocks of a prominent regional feature termed the "Lower Carbonate Aquifer" (LCA), this well provides a portal into a pristine deep ecosystem that would otherwise be very difficult to access. Analysis of the microorganisms living in this restricted oligotrophic environment provides a perspective into microbial metabolic strategies required to endure prolonged hydrogeological isolation deep underground. The isolation of this unit is demonstrated by the very low radiocarbon content $\left(4.65 \mathrm{pmc}{ }^{14} \mathrm{C}\right)$ and absence of contamination related to past nuclear testing in the overlying units. Here we present a microbiological and physicochemical characterization of one window into the NNSS portion of the DVRFS and describe the isolation of a representative bacterium from this ecosystem, DRI-13 ${ }^{\mathrm{T}}$, a novel, moderately thermophilic, strict fumarate-respiring organism belonging to the phylum Firmicutes from the deep terrestrial biosphere, here designated Thermoanaerosceptrum fracticalcis.

\section{MATERIALS AND METHODS}

\section{Field Site and Sample Collection}

Well U-3cn\#5 (Garber and Johnson, 1967; Bangerter and Giblin, 1998 ) is located in central Yucca Flat, Nevada, United States on the NNSS (latitude 37.06, longitude -116.02 , surface elevation $1223 \mathrm{~m}$ ). Yucca Flat is an arid, intermontane valley partially filled with tuffs and alluvium (260 - 290 m thickness), underlain by partially welded and zeolitized Tertiary-age ash-flow tuffs and bedded tuffs ( $\sim 536 \mathrm{~m}$ thickness). A highly fractured Paleozoic carbonate layer (colluvium transitioning to dolomite/dolomitic quartzite) of about $41 \mathrm{~m}$ thickness completes the sequence and is the source of groundwater for this study. The borehole was drilled in 1965 to a total depth of $923.5 \mathrm{mbls}, 120 \mathrm{~m}$ southwest of surface ground zero and outside the collapse chimney of the Bilby underground nuclear test conducted in 1963 (249 kt, $63.7 \mathrm{~m}$ cavity radius) (Zavarin, 2014) (Figures 1A,B). The hole intersects the local groundwater table at $493.9 \mathrm{mbls}$ and carbonate rocks at 863.2 mbls. Borehole gamma logs conducted within U$3 \mathrm{cn} \# 5$ indicated the presence of elevated radionuclides within 


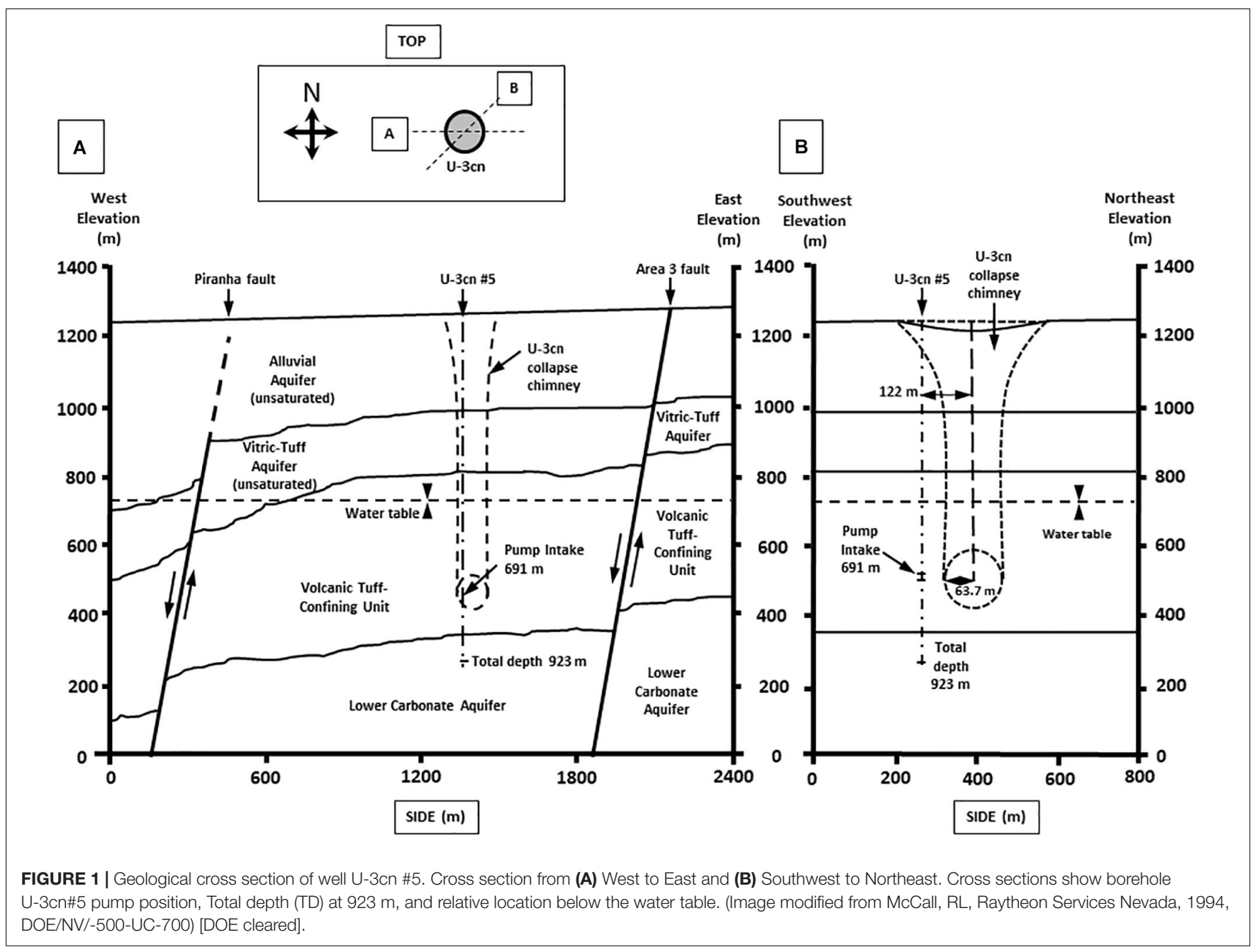

the unsaturated zone tertiary volcanic rock. These radionuclides were thought to have been emplaced by prompt injection during the underground test. Radionuclides have not been detected in the water-saturated fractured carbonates intersected by $\mathrm{U}-3 \mathrm{cn} \# 5$, indicating no impact by the nearby underground nuclear test (Thompson, 1999). This volcanic confining unit overlying the carbonate aquifer serves to hydrogeologically isolate a nearly anoxic, slightly geothermal $\left(\sim 45^{\circ} \mathrm{C}\right)$ portion of the LCA. The well is continuously cased through the vadose zone and confining unit (stainless steel below the water table) and was recompleted in 1996/1997, when the permanent 50-horsepower tandem pump used for this study was installed at $691.3 \mathrm{mbls}$. During pumping, water is obtained from an isolated open hole segment (863.2923.5 mbls) within the LCA below the casing terminus; most likely derived from distinct fractured zone in core logs at 863.5, 864.4 , and 866.2 mbls or a highly fractured zone from 868.7 to $876.3 \mathrm{mbls}$ (Bangerter and Giblin, 1998).

Prior to sampling, U-3cn\#5 was pumped and sampled on a semi-regular basis since 1967 (Total of $3 \times 10^{6} \mathrm{~m}^{3}$ of water), including March 29, 2011, the subject of this report. Water samples were obtained on the surface from an in-line sampling port affiliated with a hydrologic pump test (104.9 gpm) after removal of $440 \mathrm{~m}^{3}$ of water over a period of days via an autoclaved gas-tight manifold. Water samples for microbial cultivation and dissolved gas sampling were transferred from flowing lines (LS-24 Nuprene Tubing, Masterflex) fitted with $24 \mathrm{Ga}$ needles into sterile crimp-sealed, pre-evacuated, $\mathrm{N}_{2}$ flushed, $120 \mathrm{~mL}$ serum bottles (gas samples fixed with $5 \mu \mathrm{L}$ of saturated $\mathrm{HgCl}_{2}$ ). Samples for aqueous chemistry were collected from the flowing sample lines and analyzed offsite. Samples for microbial community analysis were collected in two sterile $8 \mathrm{~L}$ polypropylene carboys and cells collected offsite on $0.2 \mu \mathrm{m}$ filters (Sterivex, EMD Millipore, Bedford MA, 2 L per filter).

\section{Physical and Geochemical Analysis}

Field measurements of temperature, dissolved $\mathrm{O}_{2} \quad\left(\mathrm{dO}_{2}\right)$, conductivity, and $\mathrm{pH}$ were made onsite with an MP20 Sonde fitted with a flow cell (Yellow Springs Instruments, Yellow Springs, $\mathrm{OH}$ ). Most chemical analytes were obtained during routine analysis by the DOE Underground Test Area (UGTA) Program. Additional analyses were performed at the Desert Research Institute (DRI) Water Analysis Laboratory (Reno, NV, United States) or at Princeton University (Princeton, NJ, 
United States). Nitrite, nitrate, and ammonia were analyzed at DRI using Alpkem RFA 300 and Technicon Automated Colorimetric Analyzers using EPA method SM 4500- $\mathrm{NO}_{3} \mathrm{~F}$ and $\mathrm{SM} 4500-\mathrm{NH}_{4}$ F. Dionex Model ICS 2000 Ion Chromatograph was used for the measurement of $\mathrm{Cl}^{-}, \mathrm{Br}^{-}$, and $\mathrm{SO}_{4}{ }^{2-}$. A Brinkmann Metrohm Titrando automated titrator, capable of potentiometric titrations to fix inflection end points, was used in the determination of $\mathrm{CO}_{3}{ }^{2-}, \mathrm{HCO}_{3}{ }^{-}, \mathrm{pH}, \mathrm{EC}$, and $\mathrm{F}^{-}$. An OI Analytical 1030W Carbon Analyzer was used for determination of dissolved organic carbon (DOC) and total organic carbon (TOC) in water samples. A Thermo Elemental SOLAAR M5 Atomic Absorption Spectrometer with air-acetylene flame and vapor generation capabilities was used for major cation and many metal analyses.

A subset of samples were analyzed in duplicate for anions $\left(\mathrm{F}^{-}\right.$, $\left.\mathrm{Cl}^{-}, \mathrm{NO}^{2-}, \mathrm{SO}_{4}{ }^{2-}, \mathrm{Br}^{-}, \mathrm{NO}_{3}{ }^{-}, \mathrm{PO}_{4}{ }^{3-}\right)$ and for short chain fatty acids (acetate, lactate, formate, and propionate) at Princeton University using a Dionex IC25 ion chromatograph (Thermo Scientific, Waltham, MA, United States) coupled to an MSQ Plus $^{\text {TM }}$ ESI-quadrupole mass spectrometer (Thermo Scientific, Waltham, MA, United States) (Lau et al., 2014).

Total and Live/Dead cell counts were determined for groundwater samples using mfgr-provided reagents and protocols with a MicroPro Flow Cytometer (Benton Dickenson).

\section{Environmental DNA and Clone Libraries}

Planktonic microorganisms, concentrated by filtration, were extracted using the UltraClean ${ }^{\mathrm{TM}}$ Soil DNA Isolation kit (Mo Bio Laboratories Inc., Carlsbad, CA, United States), according to manufacturer's protocol amended with three freeze/thaw cycles $\left(-80^{\circ} \mathrm{C} / 65^{\circ} \mathrm{C} ; 20 \mathrm{~min}\right.$ each) at the beginning of DNA extraction procedure. Given the proximity of the site to prior nuclear testing, filters were screened for radioactivity by scintillation at the Harry Reid Center for Environmental Studies at the University of Nevada, Las Vegas as a precaution (all were below detection limits). The extracted DNA was used for PCRamplified clone libraries, universal bacterial primers 27F-YM/149 2R (AGAGTTTGATYMTGGCTCAG/TACCTTGTTACGACTT) and universal archaeal primers were used 21F/149 2R (TTCCGGTTGATCCYGCCGGA/TACCTTGTTACGACTT) to generate near-full-length 16S rRNA gene amplicons (Lane, 1991). PCR was performed using LATaq (Clontech, Mountain View, CA, United States) and thermocycler settings of $95^{\circ} \mathrm{C}$, $30 \mathrm{~s} ; 53^{\circ} \mathrm{C}, 30 \mathrm{~s} ; 72^{\circ} \mathrm{C}, 60 \mathrm{~s}$; for 30 cycles. PCR amplicons were purified with an UltraClean GelSpin DNA Purification Kit (Mo Bio Laboratories Inc., Carlsbad, CA, United States), cloned (TOPO-TA, Invitrogen, Carlsbad, CA, United States) and contigs were completely sequenced for bacteria and partially sequenced for archaea by Functional BioSciences (Madison, WI, United States) using vector primers. Contigs were generated using Sequencher ${ }^{\mathrm{TM}} 4.9$ (Gene Codes, Ann Arbor, MI, United States), aligned, matched with nearest neighbors and checked for chimeras using Silva (v1.2.11) (Glöckner et al., 2017) and MEGA 5.2 (Tamura et al., 2011).

\section{Enrichment Cultivation and Isolation}

Microbial cultivation enrichments were performed in $160 \mathrm{~mL}$ serum bottles with $25 \mathrm{~mL}$ of a custom artificial groundwater medium (AGM), composed of per liter $3.6 \mathrm{~g}$ 2-[4-(2hydroxyethyl)piperazin-1-yl]ethanesulfonic acid (HEPES), $1.5 \mathrm{~g} \mathrm{Na}_{2} \mathrm{SO}_{4}, 0.174 \mathrm{~g} \mathrm{~K}_{2} \mathrm{PO}_{4}, 0.138 \mathrm{~g}$ Resazurin, $0.4 \mathrm{~g} \mathrm{MgCl}_{2} 6$ $\mathrm{H}_{2} \mathrm{O}, 0.5 \mathrm{~g} \mathrm{KCl}, 0.268 \mathrm{~g} \mathrm{NH}_{4} \mathrm{Cl}, 0.25 \mathrm{~g} \mathrm{NaHCO}_{3}, 1 \mathrm{~mL}$ ATCC Minimal Vitamins (ATCC, Manassas, VA, United States), and $1 \mathrm{~mL}$ ATCC Minimal Minerals. AGM was prepared anaerobically using a modified Hungate technique with $600 \mathrm{mg} / \mathrm{L} \mathrm{Na} 2 \mathrm{~S} \cdot 9 \mathrm{H}_{2} \mathrm{O}$ as a reducing agent (Miller and Wolin, 1974). The water sample was maintained at $4^{\circ} \mathrm{C}$ for 2 years prior to attempting enrichments. The primary enrichment consisted of $1 \mathrm{~mL}$ inoculum from the environmental sample, incubated in AGM amended with $0.1 \%(\mathrm{w} / \mathrm{v})$ peptone (BD Bacto, Franklin Lakes, NJ, United States) at $45^{\circ} \mathrm{C}$ with a headspace of $100 \% \mathrm{~N}_{2}$. Cell numbers were monitored using a Petroff-Hausser counter (Hausser Scientific Co., Horsham, PA, United States) and an Axioskop2 Plus microscope under phase contrast. Cells reached a density of $10^{6}$ cells $/ \mathrm{mL}$ after 1 month and were subsequently transferred three times prior to final isolation by low-intensity heat shock, serial dilution, and streak plating. Heat shocks were performed first on the environmental enrichment by rapidly raising the incubation temperature during logarithmic growth from $45^{\circ} \mathrm{C}$ to $60^{\circ} \mathrm{C}$ for $1 \mathrm{~h}$ and then rapidly cooling to $45^{\circ} \mathrm{C}$. This was repeated for three transfers, the resulting cultures were then serial diluted to sub single cell concentrations. Finally, the putative isolate was streaked on anaerobic $1 \% \mathrm{w} / \mathrm{v}$ agar plates (AGM with agar added) amended with $10 \mathrm{mM}$ fumarate/0.05\% $(\mathrm{w} / \mathrm{v})$ yeast extract and one of the apparently identical colonies was selected as the type strain.

\section{Cell Growth Assays}

Growth experiments were conducted in 160-mL serum bottles, containing $25 \mathrm{~mL}$ volume of AGM and $10 \mathrm{mM}$ fumarate with a headspace of $100 \% \mathrm{~N}_{2}$. Cultivation experiments to define temperature optima were incubated at $37,45,50$, 55,60 , and $65^{\circ} \mathrm{C}$ in the dark without shaking. Cultivation experiments to determine optimal $\mathrm{pH}$ utilized alternative buffers, replacing the HEPES buffer when not appropriate. A final concentration of $10 \mathrm{mM}$ for each buffer was used to achieve the desired $\mathrm{pH}$ value. The buffers used were: 1,4Piperazinediethanesulfonic acid (PIPES) for $\mathrm{pH}$ 6.5-7.5, HEPES for $\mathrm{pH}$ 8-8.5, and 3-([1,1-Dimethyl-2-hydroxyethyl]amino)-2hydroxypropanesulfonic acid (AMPSO) for $\mathrm{pH}$ 9. All culturing optimization tests were completed in quadruplicate.

Substrate utilization was determined by transferring strain DRI- $13^{\mathrm{T}}$ three times at $55^{\circ} \mathrm{C}$ into AGM media containing $10 \mathrm{mM}$ of the following defined substrates: glucose, formate, fumarate, lactate, acteate, pyruvate, methanol, propionate, ribose, xylose, oxaloacetate, succinate, tartarate, butyrate, malate, citrate, aspartate, methionine, valine, alanine/glycine, leucine/glycine, and glutamate/glycine. Undefined substrates were added to AGM media in concentrations of $0.1 \% \mathrm{wt} / \mathrm{vol}$ for casamino acids, peptone, and yeast extract. Gas phase substrates were added to the serum bottle headspace to a pressure of 30 psi for $\mathrm{H}_{2} / \mathrm{CO}_{2}$ (80:20) and CO (100). Electron acceptors $5 \mathrm{mM}$ nitrite, $5 \mathrm{mM}$ nitrate, $10 \mathrm{mM}$ sulfate, $10 \mathrm{mM}$ sulfite, $10 \mathrm{mM}$ thiosulfate, and $0.01 \% \mathrm{wt} / \mathrm{vol}$ elemental sulfur were individually added to AGM medium with each defined and undefined substrate. Success was determined when cultures were successfully transferred three 
times and reached cell densities of $10^{8}$ cells $/ \mathrm{mL}$ by microscopy observations using a Petroff-Hauser cell counting chamber.

Co-culture experiments of strain DRI- $13^{\mathrm{T}}$ with wild type Methanothermobacter thermoautotrophicum were conducted in AGM medium containing $10 \mathrm{mM}$ fumarate or $30 \mathrm{psi}$ $\mathrm{H}_{2} / \mathrm{CO}_{2}$ (80/20 headspace) at $55^{\circ} \mathrm{C}$. Enumeration of both microorganism's growth was monitored by microscopy based on their distinct morphologies.

Fumarate depletion was monitored by high-performance liquid chromatography (HPLC). Supernatants were filtered and acidified with $200 \mathrm{mM}$ sulfuric acid to a final concentration of $5 \mathrm{mM}$. A sample of $5 \mu \mathrm{L}$ was injected into AcclaimTM OA $5 \mu \mathrm{m}$ column $(4 \times 250 \mathrm{~mm})$, (Thermo Scientific), housed in Agilent 1100 series HPLC system for each time point. Separation was achieved under an isocratic gradient at a temperature of $38^{\circ} \mathrm{C}$ and flow of $0.5 \mathrm{~mL} / \mathrm{min}$. The DAD detector was adjusted to a wavelength of $210 \mathrm{~nm}$ and full scale sensitivity. Retention times of obtained peaks were compared with known standards (Organic Acids Kit, Supelco Analytical) and the quantity calculated using linear standard curves. The results were assessed with Chromeleon 7 software.

\section{S rRNA Gene Sequence Analysis and Genomic DNA Extraction}

Strain DRI-13 ${ }^{\mathrm{T}}$ isolate was identified by centrifuging $5 \mathrm{~mL}$ of planktonic cells during logarithmic growth at $10,000 \times g$ for $15 \mathrm{~min}$ at $4^{\circ} \mathrm{C}$. DNA was extracted from the resulting cell pellet using an UltraClean Microbial DNA Isolation Kit (Mo Bio, Carlsbad, CA, United States). Universal bacterial primers 27F/1492R (5'-AGAGTTTGATCMTGGCTCAG-3'/5' ACCTTGTTACGACTT-3') were used to PCR amplify the small subunit ribosomal RNA (SSU rRNA or 16S rRNA gene) (Weisburg et al., 1991). The PCR product was then sequenced by Functional Biosciences (Madison, WI, United States) to determine identification of the isolate. With other 16S rRNA gene sequences recovered from the National Center for Biotechnology Information (NCBI) website, the sequences were aligned and phylogenetic relationships determined by Silva (v1.2.11) (Glöckner et al., 2017) and MEGA 5.2 (Tamura et al., 2011). Taxonomic classification sequences were obtained from the "List of Prokaryotic names with Standing in nomenclature" (LPSN, ${ }^{1}$ ).

High-molecular weight DNA was extracted from DRI-13 ${ }^{\mathrm{T}}$ by cultivating the organism in five, 1-L batch cultures grown on $10 \mathrm{mM}$ fumarate. Cells were harvested by centrifugation at $15,000 \times g$ for $30 \mathrm{~min}$, and DNA was precipitated and extracted by cetyltrimethyl ammonium bromide (CTAB) buffer/phenol/chloroform (Sambrook and Russell, 2001). DNA was RNase treated, quality-checked on $1 \%$ agarose gel and shipped to the DOE Joint Genome Institute (JGI) for draft sequencing using Illumina and PacBio sequencing technology (PacBio RS; Illumina HiSeq 2500). The sequences were assembled according to JGI protocols using Velvet, annotated using a suite of gene characterization tools, and made available as a part

${ }^{1}$ http://www.bacterio.net/index.html of the JGI-IMG data warehouse (Markowitz et al., 2014). The genome of DRI- $13^{\mathrm{T}}$ was released to the public as per JGI protocol and is available both through the DOE IMG platform and via NCBI (Accession\# PRJNA234897). The full length 16S rRNA gene sequence was submitted to NCBI and assigned accession number KR014122.

\section{Electron Microscopy and Sample Preparation}

For SEM, the samples were moved to a $13 \mathrm{~mm}$ Swinney micofilter holder with $0.2 \mu \mathrm{m}$ Millipore filters and dehydrated. Dehydration of the cells was done with $25 \%$ increases of ethanol for 15 min each step from 25 to $95 \%$, then three washes of $100 \%$. Once dehydrated, the filters were critical point dried with a Tousimis Samdri CPD (Tousimis, Rockville MD, United States), mounted on aluminum stubs and coated with approximately $25 \mathrm{~nm}$ layer of gold with a SPI sputter coater (SPI supplies, West Chester, PA, United States). Images were taken on a Zeiss $1450 \mathrm{EP}$ SEM at $10 \mathrm{kV}$.

Cells for transmission electron microscopy (TEM) and scanning electron microscopy (SEM) were aseptically removed from anaerobic serum bottles and immediately fixed with $2 \%$ $\mathrm{v} / \mathrm{v}$ glutaraldehyde in $0.1 \mathrm{M}$ sodium cacodylate buffer for $1 \mathrm{~h}$ at $4^{\circ} \mathrm{C}$. Cells were pelleted by centrifugation $(10,000 \times g$ for $10 \mathrm{~min}$ ) between all steps and then re-suspended each time. The sample was then rinsed with $0.1 \mathrm{M}$ sodium cacodylate buffer for 10 min each for three times and re-suspended in $1 \% \mathrm{OsO}_{4}$ in 0.1 $\mathrm{M}$ sodium cacodylate buffer for an hour at $4^{\circ} \mathrm{C}$, then rinsed in distilled water for $10 \mathrm{~min}$ twice. TEM dehydration of the cells was performed with $25 \%$ increases of ethanol for 15 min each step from 25 to $95 \%$, then three washes of $100 \%$. Samples were then infiltrated with Spurr's low viscosity resin (EMS, Hatfield, PA, United States), with increasing concentrations of $100 \%$ ethanol and resin. After three changes of $100 \%$ resin and $1 \mathrm{~h}$ between each change, the samples were then placed in a $70^{\circ} \mathrm{C}$ oven for polymerization for $12 \mathrm{~h}$. The resin was cut into $50-70 \mathrm{~nm}$ thick sections on a MT-X ultramicrotome (RMC, Tuscon, AZ, United States) and images were obtained on a JEOL 1011 TEM (JEOL, United States, Peabody, MA, United States) operating at $80 \mathrm{kV}$ and equipped with an AMT camera system.

\section{Lipid Analysis}

For analysis of cellular fatty acids, biomass was harvested from cells grown in fumarate-amended $(10 \mathrm{mM})$ mineral media for $72 \mathrm{~h}$ at $55^{\circ} \mathrm{C}$. Analysis was performed at the Center for Microbial Identification and Taxonomy (University of Oklahoma). Fatty acid methyl esters were extracted, separated, and analyzed using the Sherlock Microbial Identification System (MIDI) version 6.1 as described previously (Kampfer and Kroppenstedt, 1996; Sasser, 2001). Analysis was performed with an Agilent Technologies $6890 \mathrm{~N}$ gas chromatograph equipped with a phenyl methyl silicone fused silica capillary column (HP-Ultra 2, $25 \mathrm{~m} \times 0.2 \mathrm{~mm} \times 0.33 \mu \mathrm{m}$ film thickness) coupled with a flame ionization detector. Hydrogen was used as the carrier gas. The temperature program was preset at $170^{\circ} \mathrm{C}$ and increased at $5^{\circ} \mathrm{C}$ $\mathrm{min}^{-1}$ to a final temperature of $270^{\circ} \mathrm{C}$. The identification and 
relative abundance of each fatty acid was expressed in terms of the percentage of total fatty acids using the QTSA1 database.

\section{RESULTS}

\section{Hydrogeological Setting}

The physiological and geochemical characteristics of the water samples from the pump test of U-3cn\#5 on March 29, 2011 are presented in Table 1. Borehole water was fresh $(845 \mu \mathrm{S} / \mathrm{cm}$ or $540 \mathrm{ppm}$ TDS) (Kang and Jackson, 2016), slightly alkaline (pH 7.7), and was $44.7^{\circ} \mathrm{C}$, as recorded at the surface. The dissolved oxygen (DO) was measured at $0.19 \mathrm{mg} / \mathrm{L}$ (3.2\% of saturation), with no detectable sulfide. Reduction/oxidation potential was not measured. Total inorganic carbon (TIC) was $50.3 \mathrm{mg} \mathrm{C} / \mathrm{L}$, which at this $\mathrm{pH}$ would have been mostly bicarbonate. Major ions were defined by sodium $>$ calcium $>$ sulfate $>$ silica (53.5, 37.2, 36, and $35 \mathrm{mg} / \mathrm{L}$, respectively), followed by lesser amounts of chloride, magnesium, and potassium. Total metals were dominated by iron $(1.57 \mathrm{mg} / \mathrm{L})$, followed by lesser amounts of strontium $(248 \mu \mathrm{g} / \mathrm{L})$, manganese $(101 \mu \mathrm{g} / \mathrm{L})$, zinc $(10.9 \mu \mathrm{g} / \mathrm{L})$,

TABLE 1 | Physical and chemical characteristics of source water from borehole U-3cn\#5.

\begin{tabular}{|c|c|c|c|}
\hline Latitude & 37.06 & $\mathrm{Mn}(\mu \mathrm{g} / \mathrm{L})$ & 101 \\
\hline Longitude & -116.02 & Mo ( $\mu \mathrm{g} / \mathrm{L})$ & 4.8 \\
\hline Depth of sample (m) & $863-923$ & $\mathrm{Zn}(\mu \mathrm{g} / \mathrm{L})$ & 10.9 \\
\hline Total Depth of well (m) & 924 & $\mathrm{Cu}(\mu \mathrm{g} / \mathrm{L})$ & $<0.09$ \\
\hline Sampling method & Pump & $\operatorname{Cr}(\mu \mathrm{g} / \mathrm{L})$ & $<0.18$ \\
\hline Temperature $\left({ }^{\circ} \mathrm{C}\right)$ & 44.7 & $\mathrm{Ni}(\mu \mathrm{g} / \mathrm{L})$ & 2.6 \\
\hline $\mathrm{pH}$ & 7.69 & $U(\mu \mathrm{g} / \mathrm{L})$ & 0.83 \\
\hline Rock type & carbonate & $\mathrm{Pb}(\mu \mathrm{g} / \mathrm{L})$ & 0.072 \\
\hline $\mathrm{DO}(\mathrm{mg} / \mathrm{L})$ & 0.193 & $\operatorname{Sr}(\mu \mathrm{g} / \mathrm{L})$ & 248 \\
\hline DO (\%Sat.) & 3.2 & Cs $(\mu \mathrm{g} / \mathrm{L})$ & 2.11 \\
\hline${ }^{3} \mathrm{H}(\mathrm{pCi} / \mathrm{L})$ & $<6.5$ & $W(\mu \mathrm{g} / \mathrm{L})$ & 0.49 \\
\hline TOC (mg C/L) & 1.5 & Acetate (mg/L) & 0.4 \\
\hline TIC (mg C/L) & 50.3 & Lactate (mg/L) & 0.4 \\
\hline Live/Dead Cell counts & 4245 & Formate (mg/L) & 0.65 \\
\hline Total cell counts & 10887 & Propionate (mg/L) & $<0.01$ \\
\hline Conductivity $(\mu \mathrm{S} / \mathrm{cm})$ & 845 & Fumarate (mg/L) & $<0.01$ \\
\hline Turbidity (NTU) & 3.675 & $\mathrm{He}(\%$ vol/vol) & $<0.01$ \\
\hline $\mathrm{SO}_{4}{ }^{2-}(\mathrm{mg} / \mathrm{L})$ & 36 & $\mathrm{H}_{2}(\% \mathrm{vol} / \mathrm{vol})$ & $<0.01$ \\
\hline $\mathrm{NO}_{3}^{-}(\mathrm{mg} / \mathrm{L})$ & 0.26 & $\mathrm{O}_{2}(\% \mathrm{vol} / \mathrm{vol})$ & 17.1 \\
\hline $\mathrm{NO}_{2}^{-}(\mathrm{mg} / \mathrm{L})$ & $<0.14$ & $\mathrm{~N}_{2}$ (\% vol/vol) & 65.0 \\
\hline $\mathrm{NH}_{4}+(\mathrm{mg} / \mathrm{L})$ & 0.05 & $\mathrm{CO}_{2}(\% \mathrm{vol} / \mathrm{vol})$ & 16.9 \\
\hline $\mathrm{PO}_{4}{ }^{3-}(\mathrm{mg} / \mathrm{L})$ & 0.033 & $\mathrm{CH}_{4}(\% \mathrm{vol} / \mathrm{vol})$ & 0.17 \\
\hline $\mathrm{SiO}_{2}(\mathrm{mg} / \mathrm{L})$ & 35 & $\mathrm{C}_{2} \mathrm{H}_{6}(\% \mathrm{vol} / \mathrm{vol})$ & $<0.01$ \\
\hline $\mathrm{Cl}(\mathrm{mg} / \mathrm{L})$ & 27.4 & $\mathrm{C}_{3} \mathrm{H}_{8}(\% \mathrm{vol} / \mathrm{vol})$ & $<0.01$ \\
\hline $\mathrm{Na}(\mathrm{mg} / \mathrm{L})$ & 53.5 & iso- $\mathrm{C}_{4} \mathrm{H}_{10}(\% \mathrm{vol} / \mathrm{vol})$ & $<0.002$ \\
\hline $\mathrm{K}(\mathrm{mg} / \mathrm{L})$ & 8.5 & $\mathrm{n}-\mathrm{C}_{4} \mathrm{H}_{10}(\%$ vol/vol $)$ & 0.002 \\
\hline $\mathrm{Ca}(\mathrm{mg} / \mathrm{L})$ & 37.2 & $\mathrm{~d}^{13} \mathrm{C} \mathrm{CO}_{2}$ (in \%o V-PDB) & -12.8 \\
\hline $\mathrm{Mg}(\mathrm{mg} / \mathrm{L})$ & 16.5 & $\mathrm{~d}^{13} \mathrm{C}$ Methane (in \%o V-PDB) & b.d. \\
\hline $\mathrm{Br}(\mathrm{mg} / \mathrm{L})$ & 0.09 & $d^{2} \mathrm{H}(\%)$ & -108 \\
\hline $\mathrm{Fe}(\mathrm{mg} / \mathrm{L})$ & 1.57 & ${ }^{14} \mathrm{C}(\mathrm{pmc})$ & 4.65 \\
\hline
\end{tabular}

b.d., below detection limit of instrument. and molybdenum $(4.8 \mu \mathrm{g} / \mathrm{L})$. Inorganic nitrogen was dominated by ammonium and nitrate, which were detected at $0.05 \mathrm{mg} / \mathrm{L}$ and $0.26 \mathrm{mg} / \mathrm{L}$; while nitrite was below the $0.01 \mathrm{mg} / \mathrm{L}$ detection limit. Phosphate was detectable at $0.033 \mathrm{mg} / \mathrm{L}$. Total organic carbon (TOC) was present at $1.5 \mathrm{mg} / \mathrm{L}$, a substantial proportion of which is represented by the short chain fatty acids formate, acetate, and lactate, measured at $0.65,0.4$, and $0.4 \mathrm{mg} / \mathrm{L}$, respectively. Propionate and fumarate were below detection limits. Tritium, a marker for the impact of nuclear device testing, was $<7 \mathrm{pCi} / \mathrm{L}$. Stable isotope signatures of $\mathrm{d}^{13} \mathrm{C}$ for dissolved inorganic carbon (DIC) of $-12.8 \%$, and $\mathrm{d}^{2} \mathrm{H}$ of $-108 \%$ were detected as well.

\section{Indigenous Microbial Communities}

Cell enumeration indicated a total planktonic cell density in borehole water of $1.1 \times 10^{4}$ cells $/ \mathrm{mL}$. Of these, a substantial proportion ( half, $4.2 \times 10^{3}$ cells $\left./ \mathrm{mL}\right)$ were reported as viable based on the output of a flow cytometric Live/Dead assay. To gain a better understanding of microbial community structure in these samples, total DNA from 0.2 micron filters was amplified by PCR and used to construct bacterial and archaeal 16S rRNA gene libraries. A total of 84 complete ( $\sim 1400 \mathrm{bp}$ ) bacterial sequences were constructed and consolidated into 23 representative taxa that were submitted to NCBI (Accession \#:MK682771MK682793). A total of 35 partial ( $~ 850 \mathrm{bp})$ archaeal sequences were consolidated into 3 representative taxa that were also submitted to NCBI (Accession \#: MK675956-MK675958). Bacterial communities were dominated by Proteobacteria (81\% - a mix of Alphaproteobacteria, Betaproteobacteria, Deltaproteobacteria, and Gammaproteobacteria), Acidobacteria (11\%), and Firmicutes (8\%) (Supplementary Figure S1). Among the archaea, clones were distributed between Euryarchaeota (71\%) predominantly a species related to Methanothermobacter thermautotrophicus and Methanococcus igneus, and Crenarchaeota (29\%) (Supplementary Figure S2). Close relatives of strain DRI-13 ${ }^{\mathrm{T}}$ were not detected in these libraries.

\section{Isolate Properties and Identification}

Strain DRI- $13^{\mathrm{T}}$ was purified from a $45^{\circ} \mathrm{C}$ anaerobic enrichment in a synthetic groundwater medium supplemented with $0.1 \%$ $\mathrm{wt} / \mathrm{vol}$ peptone as the sole carbon and energy source. After 3 weeks of isolation techniques (see methods), the DRI-13 ${ }^{\mathrm{T}}$ colonies were $0.5 \mathrm{~mm}$ in diameter, circular (with entire margins), glossy, and convex. The resulting isolate was a Gram-stainpositive bacillus $(\sim 2-6 \mu \mathrm{m}$ long and $\sim 0.5 \mu \mathrm{m}$ wide) which reached a density of $\sim 10^{6}$ cells $/ \mathrm{mL}$ in culture. The strain was motile and was observed by phase contrast microscopy to form a central endospore. Phylogenetic analysis of the full-length 16S rRNA gene (GenBank accession no. KR014122) indicated that DRI- $13^{\mathrm{T}}$ possessed $90.0 \%$ similarity to Pelotomaculum propionicicum (Imachi et al., 2007) and P. thermopropionicum (Imachi et al., 2002) and $88.0 \%$ similarity to Desulfotomaculum gibsoniae (Kuever et al., 1999). The most closely related $16 \mathrm{~S}$ rRNA gene sequences in available databases affiliated with as-yet uncultured bacteria discovered from subsurface environments in Denmark (99.0\% similarity, AY538172.1), Australia (97.0\% similarity, EU400652.1), and Japan (97.0\% 


\section{Family}

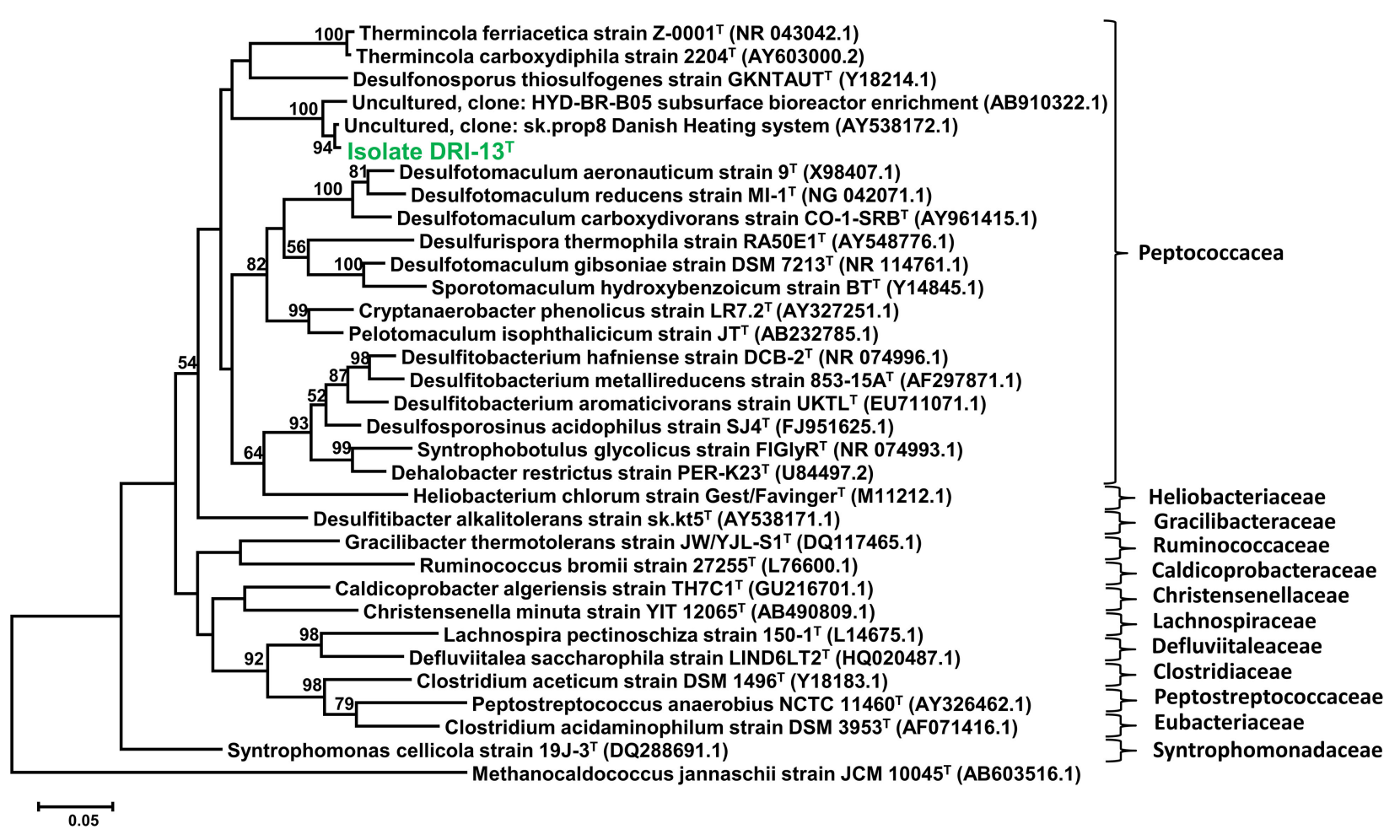

FIGURE 2 | Taxonomic placement of isolate DRI-13 ${ }^{\top}$ by full length $16 \mathrm{~S}$ rRNA genes aligned by SILVA (v1.2.11), and maximum-likelihood method based on 1,000 permutations of all bacterial families with nomenclature standing within the class Clostridiales. The scale bar represents $5 \%$ identity dissimilarity between sequences.

similarity, AB910322.1). By comparing the 16S rRNA gene sequence to selected type strains representing all families under the order Clostridiales, it appears strain DRI-13 $3^{\mathrm{T}}$ is a previously undescribed genus within the family Peptococcacea (Figure 2).

\section{Physiological Characterization of Strain DRI-13 ${ }^{\top}$}

Analysis by SEM of isolate DRI- $13^{\mathrm{T}}$ revealed a distinctive thin rod-shaped morphology characterized by an average length of 4$6 \mu \mathrm{m}$ and $0.5 \mu \mathrm{m}$ width (Figure 3A). TEM revealed a distinct inner and outer membrane with an electron-dense matrix and what appears to be a vacuole (Figure 3B).

Strain DRI- $13^{\mathrm{T}}$ is a fastidious obligate anaerobe. The isolate grew poorly with $0.1 \% \mathrm{wt} / \mathrm{vol}$ casamino acids, $10 \mathrm{mM}$ glucose, $0.1 \% \mathrm{wt} / \mathrm{vol}$ peptone, or $0.1 \% \mathrm{wt} / \mathrm{vol}$ yeast extract when used as the sole carbon and energy source. No growth was observed when supplemented with $\mathrm{H}_{2} / \mathrm{CO}_{2}$ (80:20), CO, formate, lactate, acetate, pyruvate, $\mathrm{CH}_{4}$, methanol, propionate, ribose, xylose, oxaloacetate, succinate, tartarate, butyrate, malate, citrate, aspartate, methionine, and valine. Stickland reactions of alanine/glycine, leucine/glycine, and glutamate/glycine also failed to support growth (Nisman, 1954). Likewise, accessory electron acceptors including nitrite, nitrate, sulfate, sulfite, thiosulfate, and elemental sulfur failed to stimulate growth. The only substrate tested that was successful in supporting growth was fumarate (Table 2).

Specific growth rates of DRI- $13^{\mathrm{T}}$ during anaerobic respiration on fumarate display a maximal specific growth rate of $0.4 \mathrm{~h}^{-1}$ under optimal conditions of temperature and $\mathrm{pH}\left(55^{\circ} \mathrm{C}\right.$ and $\mathrm{pH}$ 8.0) (Figures 4A,B). Metabolic analysis of DRI- $13^{\mathrm{T}}$ shows growth vs. substrate utilization experiment ( $30 \mathrm{mM}$ fumarate) performed over $70 \mathrm{~h}$ (Figure 5). This experiment revealed an initial lag phase of 15-20 h, after which cellular growth commenced along with consumption of fumarate, reaching the lower limit of detection at $65 \mathrm{~h}$. Temporally corresponding to the depletion of fumarate was the coincident production of succinate and acetate, which reached maxima at about $50 \mathrm{~h}$. These experiments revealed a conversion rate of one equivalent of fumarate to approximately 0.83 and 0.33 equivalents of succinate and acetate.

Lipid analysis indicates that the major fatty acids (>10\%) present for strain DRI-13 ${ }^{\mathrm{T}}$ are the branched-chain fatty acid iso- $\mathrm{C}_{15: 0}(22.8 \%)$, straight-chain $\mathrm{C}_{15: 0}(15.0 \%), \mathrm{C}_{16: 0}(12.0 \%)$, and $\mathrm{C}_{14: 0}(11.6 \%)$, as compared to phylogenetically related bacteria (Table 3 ).

\section{Genome Sequencing and Analysis}

High-quality genomic DNA was extracted from isolate DRI$13^{\mathrm{T}}$ for genome sequencing by the DOE Joint Genome Institute 

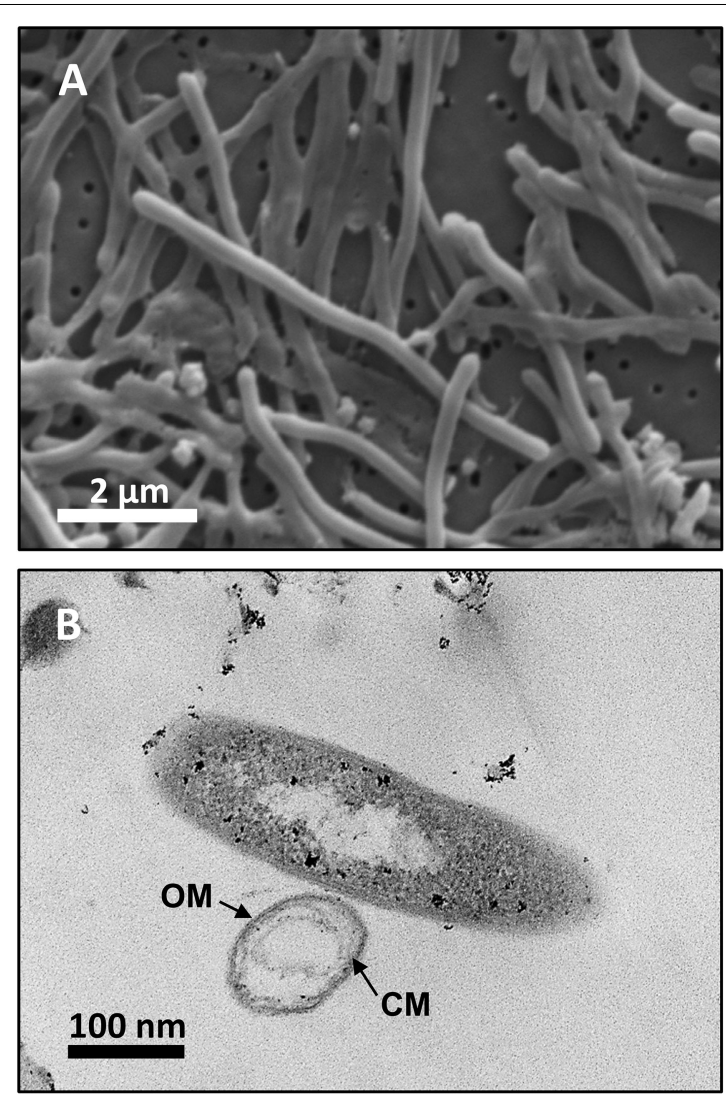

FIGURE 3 | Microscopy images of strain DRI-13 ${ }^{\top}$ : (A) scanning electron micrograph showing average 4-6 $\mu \mathrm{m}$ length morphology; (B) transmission electron micrograph showing outer membrane (OM) and cytoplasmic membrane (CM).

(JGI, JGI GOLD Gi0054453, NCBI Taxonomic ID 1449126, and Assembly \#ASM74602v1). The completed draft genome of DRI$13^{\mathrm{T}}$ is $3,649,665 \mathrm{bp}$, with an average $\mathrm{G}+\mathrm{C}$ content of $45 \%$ and composed of 105 contigs (Supplementary Table S1). A total of 3,749 genes were identified, of which 3,671 (98\%) are predicted to code for proteins (PCGs). Predicted function could be assigned to 2874 (77\%) of the total number of PCGs, while 797 (21\%) had no known functional prediction ${ }^{2}$. Genes were identified for assimilatory/dissimilatory sulfate and sulfite reduction, anaerobic fumarate respiration, tripartite ATP-independent secondary passive transport, endospore formation/germination, and flagella biosynthesis (Supplementary Table S2).

\section{DISCUSSION}

Within North America's Basin and Range (B\&R) physiographic province lies the Great Basin (Grayson, 2011), a hydrogeologically defined, internally draining province that comprises portions of the US states of California, Oregon, Idaho, Arizona, and most of Nevada. Fault-controlled flow of deep

${ }^{2}$ https://img.jgi.doe.gov groundwater within this tectonic extensional zone results in hydrographic basins and sub-basins (Winograd and Thordarson, 1975, Winograd et al., 2005), with the subject of this study, the Death Valley Regional Flow System (DVRFS), being the largest. Borehole U-3cn\#5 (Figure 1) intercepts a hydrologically confined lobe of the DVRFS's and represents a novel window for deep biosphere study of the Basin and Range and extensional zones in general.

The fracture carbonate-hosted aquifer from which DRI$13^{\mathrm{T}}$ was isolated possesses chemistries (e.g., circumneutral $\mathrm{pH}$, relatively high sulfate, low TOC) and overall microbial community structure typical of subsurface fractured carbonate aquifers studied elsewhere (Table 1) (Hohnstock-Ashe et al., 2001; Farnleitner et al., 2005; Gihring et al., 2006; Pfiffner et al., 2006; Park et al., 2009). Nutrients, fixed organic carbon, and energy resources are all relatively limited in this environment. As with other fractured carbonate aquifers, it is unclear how microbial populations are sustained, especially with regard to carbon sources (Hohnstock-Ashe et al., 2001). In U-3cn\#5, rRNA gene libraries reveal a microbial community composed of predicted thermophilic anaerobes from the domain Bacteria and Archaea (Supplementary Figures S1, S2). The geothermal/carbonate-controlled nature of this subsurface environment makes it a distinct environment compared to surrounding monitoring wells, which are emplaced in shallower lower temperature systems and other rock types (e.g., volcanics and alluvium), with one exception: borehole BLM-1. Located approximately $75 \mathrm{~km}$ South of U-3cn\#5 in the discharge zone of the DVRFS, this latter well intersects anoxic geothermal waters $\left(57^{\circ} \mathrm{C}\right)$ of the regional fractured carbonate aquifer. In spite of this distance, these two wells share similar bacterial and archaeal profiles, including the presence of important marker subsurface bacteria such as "Candidatus Desulforudis audaxviator," Desulfotomaculum putei, and the archaeon Methanothermobacter thermautotrophicus (Chivian et al., 2008; Thomas et al., 2013; Sackett, 2018).

Enrichment cultivations from U-3cn\#5 water samples in a strictly anaerobic minimal salts medium amended with peptone produced a slowly growing thermophilic bacillus after $\sim 1$ month at $50^{\circ} \mathrm{C}$. Sugar and short chain carbohydrate substrates did not promote growth (Table 2). While not directly detected in the subsurface environment of $U-3 \mathrm{cn} \# 5$, the citric acid cycle intermediate fumarate was the only substrate that enabled routine culturing of the microorganism. Isolation techniques yielded a pure culture which was given the strain name, DRI-13 ${ }^{\mathrm{T}}$. Analysis of the 1463 nucleotide $16 \mathrm{~S}$ rRNA gene sequence revealed that DRI- $13^{\mathrm{T}}$ affiliates at the species level with uncultured clones from other geothermally influenced subsurface locations including Japan, Australia (unpublished), and Denmark (AB910322.1, EU400652.1, AY538172.1) (Kjeldsen et al., 2007; Baito et al., 2015). Within the family Peptococcaceae, DRI- $13^{\mathrm{T}}$ is most closely related ( $\sim 90.0 \%$ similarity to the $16 \mathrm{~S}$ rRNA gene) to three type strains Pelotomaculum propionicicum, $P$. thermopropionicum, and $P$. isophthalicicum. This establishes DRI- $13^{\mathrm{T}}$ as a novel genus using the parameters defined by Yarza et al. (2014) (Figure 2). Of these phylogenetic relatives, only $P$. thermopropionicum share thermophilic characteristics and utilization of fumarate 
TABLE 2 | Carbon and electron utilization of DRI-13 ${ }^{\top}$ and closest relatives.

\begin{tabular}{|c|c|c|c|}
\hline Characteristic & DRI-13 ${ }^{\top}$ & $\begin{array}{c}\text { Pelotomaculum } \\
\text { propionicicum DSM } \\
15578^{1}\end{array}$ & $\begin{array}{c}\text { Pelotomaculum } \\
\text { thermopropionicum } \\
\text { DSM } 13744^{2}\end{array}$ \\
\hline $\begin{array}{l}\text { Isolation source } \\
\text { and depth }\end{array}$ & $\begin{array}{l}\text { Nevada well } \\
\text { U-3cn\#5 at } \\
0.7 \mathrm{~km}\end{array}$ & $\begin{array}{c}\text { Anaerobic sludge } \\
\text { blanket reactor }\end{array}$ & $\begin{array}{c}\text { Anaerobic sludge } \\
\text { blanket reactor }\end{array}$ \\
\hline Morphology & Rod & Rod & Rod \\
\hline Cell size $(\mu \mathrm{m})$ & $0.5 \times 6.0$ & $1.0 \times 3.0$ & $0.7 \times 2.0$ \\
\hline Motility & Yes & No & No \\
\hline Spore former & Yes & Yes & Yes \\
\hline Spore location & Central & Central & Central \\
\hline $\begin{array}{l}\text { Optimal } \\
\text { Temperature for } \\
\text { growth }\left({ }^{\circ} \mathrm{C}\right)\end{array}$ & 55 & 37 & 55 \\
\hline $\begin{array}{l}\text { Temperature } \\
\text { range }\left({ }^{\circ} \mathrm{C}\right)\end{array}$ & $35-65$ & $25-45$ & $45-65$ \\
\hline $\begin{array}{l}\text { Optimal pH for } \\
\text { growth (range) }\end{array}$ & $3.0(7.0-8.5)$ & $7.0(6.5-7.4)$ & $7.0(6.5-8.0)$ \\
\hline $\begin{array}{l}\mathrm{NaCl} \text { limit of } \\
\text { growth (mM) }\end{array}$ & 100 & 85 & 68 \\
\hline $\begin{array}{l}\text { Genome } \\
\text { Sequenced }\end{array}$ & Yes & No & Yes \\
\hline $\begin{array}{l}\text { Doubling time } \\
\text { (hours) }\end{array}$ & 2.5 & 120 & 14.5 \\
\hline \multicolumn{4}{|l|}{$\begin{array}{l}\text { Utilization of } \\
\text { electron/carbon } \\
\text { donors }\end{array}$} \\
\hline $\mathrm{H}_{2} / \mathrm{CO}_{2}$ & - & - & - \\
\hline $\mathrm{CO}$ & - & ND & ND \\
\hline Formate & - & - & - \\
\hline Lactate & - & - & $+^{*}$ \\
\hline Acetate & - & - & - \\
\hline Pyruvate & - & - & + \\
\hline Methane & - & ND & ND \\
\hline Methanol & - & - & - \\
\hline Propionate & - & + & $+^{*}$ \\
\hline Ribose & - & - & - \\
\hline Glucose & $(+)$ & - & - \\
\hline Xylose & - & - & - \\
\hline $\begin{array}{l}\text { Casamino } \\
\text { acids }\end{array}$ & $(+)$ & - & - \\
\hline Peptone & $(+)$ & - & + \\
\hline Yeast Extract & $(+)$ & - & + \\
\hline Fumarate & + & - & - \\
\hline Oxaloacetate & - & ND & ND \\
\hline Succinate & - & - & - \\
\hline Tartarate & - & ND & ND \\
\hline Butyrate & - & - & - \\
\hline Malate & - & - & - \\
\hline Citrate & - & ND & ND \\
\hline Aspartate & - & - & ND \\
\hline Methionine & - & ND & ND \\
\hline Alanine + glycine & - & - & ND \\
\hline Leucine + glycine & - & - & ND \\
\hline Glutamate + glycine & - & - & ND \\
\hline Valine & - & ND & ND \\
\hline
\end{tabular}

(Continued)
TABLE 2 | Continued

\begin{tabular}{|c|c|c|c|}
\hline Characteristic & DRI-13 ${ }^{\top}$ & $\begin{array}{c}\text { Pelotomaculum } \\
\text { propionicicum DSM } \\
15578^{1}\end{array}$ & $\begin{array}{l}\text { Pelotomaculum } \\
\text { thermopropionicum } \\
\text { DSM } 13744^{2}\end{array}$ \\
\hline
\end{tabular}

\section{Utilization of electron}

acceptors

Fumarate

Nitrite

Nitrate

Sulfate

Thiosulfate

Sulfite

Inorganic Sulfur

ND, not determined. (), limited growth observed over 2-3 weeks. *, only in coculture with Methanothermobacter themautotrophicus strain $D H^{T}$. -, no observed growth; +, growth was observed. ${ }^{1}$ Imachi et al. (2007). ${ }^{2}$ machi et al. (2002).

(Table 2). Unlike DRI-13 ${ }^{\mathrm{T}}, P$. thermopropionicum can utilize a wider range of substrates and is described under certain conditions to support a syntrophic interaction with the methanogen Methanothermobacter thermoautotrophicus. The most abundant archaeon in our U-3cn\#5 rRNA gene libraries was $M$. thermoautotrophicus ( $71 \%$ of reads). P. propionicicum and $P$. isophthalicicum have been reported to have syntrophic interactions with other methanogens as well, though no interactions were established between DRI- $13^{\mathrm{T}}$ and an isolated wild type $M$. thermoautotrophicum from the borehole. Growth combinations only resulted in DRI- $13^{\mathrm{T}}$ becoming the majority within the culture bottle and causing no change in growth performance with or without $M$. thermoautotrophicum (not shown).

Examination of DRI-13 ${ }^{\mathrm{T}}$ by SEM indicates a bacillus-type morphology, averaging $6 \mu \mathrm{m}$ in length and $0.5 \mu \mathrm{m}$ width (Figure 3A). TEM reveals features of the outer membrane and cytoplasmic membrane, including what appears to be a vacuole (Figure 3B), though it is possible that the space within the cell may be an artifact from TEM preparation. If real, the presence of a vacuole may explain an apparent buoyant property of DRI$13^{\mathrm{T}}$ cells requiring centrifugation times greater than $30 \mathrm{~min}$ at or above $15,000 \times g$, which is typical for very small cells or for cells with natural buoyancy. Lab-standard cells from the phylum Firmicutes, such as Desulfotomaculum putei, can be pelleted with less rigorous effort similar to E. coli. While not a feature noted in other subsurface microorganisms, it is conceivable that innate buoyancy control could be advantageous to fracture-dwelling subsurface microorganisms during planktonic growth.

Measureable DRI-13 ${ }^{\mathrm{T}}$ growth was observed to occur between $37^{\circ} \mathrm{C}$ (minimum) and $65^{\circ} \mathrm{C}$ (maximum). While the environmental temperature of $\mathrm{U}-3 \mathrm{cn} \# 5$ was recorded at $44.7^{\circ} \mathrm{C}$, the optimal temperature for DRI- $13^{\mathrm{T}}$ is $55^{\circ} \mathrm{C}$ (Figure $4 \mathrm{~A}$ ). Although not determined, the in situ temperature from the interval where DRI- $13^{\mathrm{T}}$ was obtained was likely higher than that recorded at the wellhead due to the long distance pumped water was lifted through presumably cooler conditions in the aquifer above the confining layer and $\sim 500 \mathrm{~m}$ of vadose zone. As might be expected for an organism adapted to strongly 

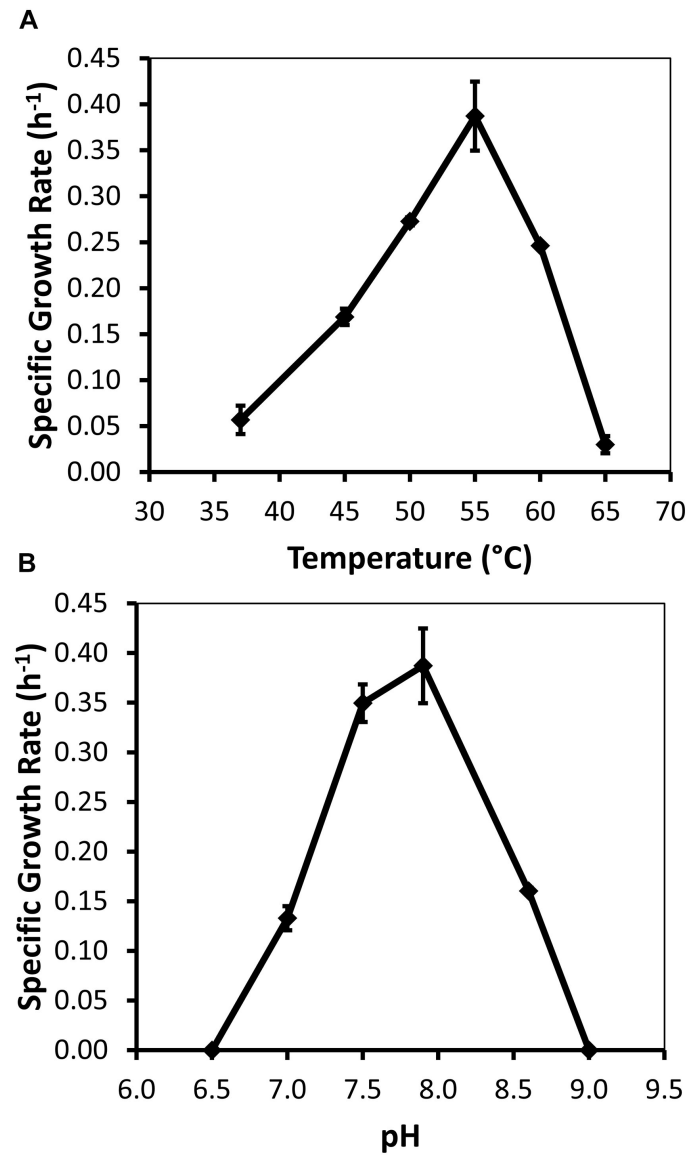

FIGURE 4 | Growth characteristics of strain DRI-13 $13^{\top}$ for: (A) optimal temperature of $55^{\circ} \mathrm{C}$; and (B) optimal pH of 8. Data points averaged from quadruplicate cultures using a standardized medium of salts with $10 \mathrm{mM}$ fumarate.

buffered carbonate aquifers, the $\mathrm{pH}$ tolerance of DRI-13 ${ }^{\mathrm{T}}$ is narrow, with observable growth occurring only between 7.0 and 8.5, and optimal growth at $\mathrm{pH} 8.0$ (Figure 4B). As compared to close relatives, the optimal temperature is similar to $P$. thermopropionicum and $P$. propionicicum $\left(55^{\circ} \mathrm{C}\right.$ and $37^{\circ} \mathrm{C}$ ). The growth rate of DRI- $13^{\mathrm{T}}$ appears to be substantially faster, doubling every $2.5 \mathrm{~h}$, as opposed to 14.5 and $120 \mathrm{~h}$ for $P$. propionicicum and $P$. thermopropionicum, respectively (Imachi et al., 2002, 2007). This faster growth rate possibly reflects the independent lifestyle of DRI- $13^{\mathrm{T}}$ as opposed to the syntrophic associations of the others. In addition, cells cultured beyond stationary phase (approximately $48 \mathrm{~h}$ ) exhibit endospore formation, as observed by microscopy and the presence of endospore related genes (Supplementary Table S2). While no discernable cellular movement was consistently observed, DRI- $13^{\mathrm{T}}$ genome appears to have flagella related genes as well (Supplementary Table S2).

Lipid analysis indicates that the major fatty acids $(>10 \%)$ for strain DRI-13 ${ }^{\mathrm{T}}$ are the branched-chain fatty acid iso$\mathrm{C}_{15: 0}(22.8 \%)$ along with the straight-chain $\mathrm{C}_{15: 0}$ (15.0\%), $\mathrm{C}_{16: 0}(12.0 \%)$ and $\mathrm{C}_{14: 0}(11.6 \%)$. The higher proportion of the branched-chain iso- $\mathrm{C}_{15: 0}$ in strain DRI- $13^{\mathrm{T}}$ is also characteristic of its nearest neighbor, $P$. thermopropionicum strain $\mathrm{SI}^{\mathrm{T}}$ in which iso- $\mathrm{C}_{15: 0}$ represents the majority of all fatty acids at $76.4 \%$ (Imachi et al., 2002), and in P. terephthalicicum strain $\mathrm{JT}^{\mathrm{T}}$ (28.7\%) (Qiu et al., 2006), Cryptanaerobacter phenolicus strain LR7. $2^{\mathrm{T}}$ (Juteau et al., 2005), and Desulfotomaculum gibsoniae Groll $^{\mathrm{T}}$ (Kuever et al., 1999) (Table 3). While the overall fatty acid methyl ester (FAME) profile for strain DRI- $13^{T}$ clearly differentiates it from its nearest phylogenetic neighbors, the significant percentage of the straight-chain fatty acid $\mathrm{C}_{15: 0}$ is a defining characteristic, as it is not present in other closely related species, with the exception of $C$. phenolicus strain LR7. $2^{\mathrm{T}}$, in which it is only a minor component (Juteau et al., 2005). Interestingly, C15 lipids were not detected in any of 44 fracture and mine water samples from a comprehensive survey of environmental lipids in the ultradeep mines of South Africa (Pfiffner et al., 2006). Another defining characteristic is the detection of $\mathrm{C}_{16: 1 \omega} \mathrm{c} / \mathrm{C}_{16}: 1 \omega 6 \mathrm{c}(5.8 \%)$, which is not present in other phylogenetic neighbors such as C. phenolicus strain LR7. $2^{\mathrm{T}}$ (Juteau et al., 2005), and D. gibsoniae strain $\mathrm{Groll}^{\mathrm{T}}$ (Kuever et al.,

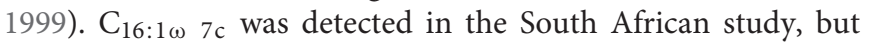
statistically corresponded with mine service water samples rather than pristine fracture water.

Fumarate catabolism was typical as described previously in other Firmicutes (Dorn et al., 1978; Imachi et al., 2002). Highpressure liquid chromatography (HPLC) detected the removal of fumarate and the concomitant production of succinate and acetate. This supports the idea that fumarate is both being metabolized and used as an electron acceptor in anaerobic respiration (Figure 5). No other observable products such as oxalate, tartrate, lactate, malate, citrate, or propionate were observed by HPLC. Headspace pressure in culture bottles remained stable $(\sim 1$ bar) with no obvious over-pressurization. The source of fumarate in the subsurface is unclear. Gelling agents associated with drilling can be a source of fumarate (Borchardt, 1989). However, in this case residue from the drilling of U-3cn\#5 may be unlikely given the borehole age (1965) and its flushing with multiple millions of liters of water pumped over the years. Samples of $1 \mathrm{~g}$ fractured carbonate from $\mathrm{U}$ $3 \mathrm{cn} \# 5$ (NNSS Core Library), aseptically crushed, extracted with $5 \mathrm{~mL}$ boiling water, concentrated, and analyzed on HPLC, did not contain detectable levels of fumarate (data not shown). It is more likely that DRI- $13^{\mathrm{T}}$ is cryptically biodegrading the waste products or endogenous decay derived from other members of the microbial community (Béranger et al., 2006). Since DRI-13 ${ }^{\mathrm{T}}$ does not seem to be a dominant microbial community member (Supplementary Figure S1), it is possible that its relatively low representation is the result of occupying a narrow niche focusing on fumarate respiration or is a relic from a period after drilling when fumarate might have been present.

Assembly of the DRI- $13^{\mathrm{T}}$ draft genome from a single library prep resulted in 105 contigs. Complete coverage of the genome failed in regions where repetitive intergenic sequences (mobile elements), hypothetical proteins, or clustered regularly interspaced short palindromic repeats (CRISPR) arrays were present. The estimated genome size is $3,649,665$ with a $\mathrm{G}+\mathrm{C}$ content of $45 \%$. This is comparable to close relatives with 


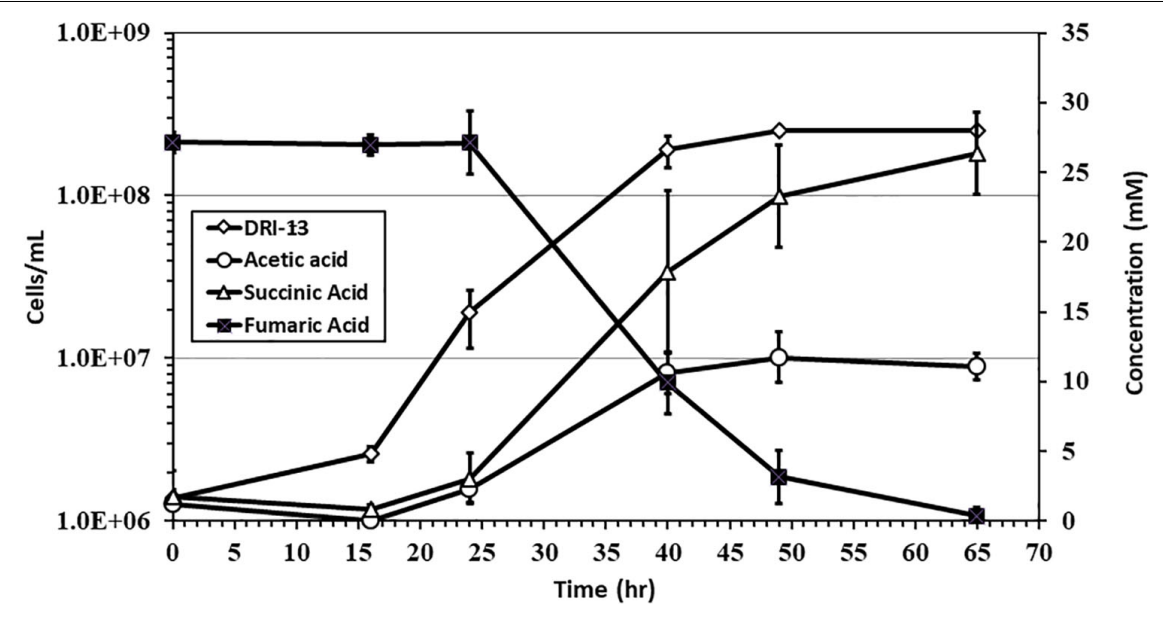

FIGURE 5 | Growth of DRI-13 ${ }^{\top}$ on $30 \mathrm{mM}$ fumarate and metabolic end products: open diamonds, cell density; filled squares, fumarate depletion; filled triangles, succinate production; filled circles, acetate production. Each data point is an average of triplicate samples with standard deviation error bars.

sequenced genomes such as D. gibsonia (4.85 Mbp) and P. thermopropionicum (3.02 Mbp). Distribution of nucleotides and genes across the 105 contigs range from 1,045 to 193,268 bases (average 34,759 bases per contig), with 2 to 203 annotated genes (average 36 genes per contig). The JGI/IMG annotation gene calling algorithms predict 3,749 genes in DRI-13 ${ }^{\mathrm{T}}$ with $77 \%$ of them functionally assigned (Supplementary Table S1). Analysis of the metabolic capability of the DRI-13 ${ }^{\mathrm{T}}$ genome indicates core genes for glycolysis/gluconeogenesis, fatty acid biosynthesis, and amino acid metabolism. Homologs for assimilatory or dissimilatory sulfate and sulfite reduction ( $d s r A$, $d s r B$, and $d s r D$ ) are present. However, sulfide production was never detected when sulfate was present in the media. Amino acid analysis of the $d s r$ genes show an identity of $84 \%$ to $99 \%$ similarity to Desulfitobacter alkalitolerans, which was isolated from a Danish geothermal heating system, a site where an uncultured 16S rRNA gene with exact homology to DRI-13 ${ }^{\mathrm{T}}$ had been sequenced (Nielsen et al., 2006; Kjeldsen et al., 2007).

Examination of the anaerobic fumarate respiration pathway revealed that core fumarate catabolic and related genes are present within the genome. Some of the genes for fumarate respiration have undergone duplication generating paralogs (Supplementary Table S2). The metabolic pathway for fumarate respiration converts three fumarate molecules to one acetate and two succinate molecules (Supplementary Figures S3A,B). The gene for the enzyme fumarase is present in the genome and can reversibly convert fumarate by hydration to malate or malate to fumarate by dehydration. The decarboxylation of the malate molecule to pyruvate is completed by NADP dependent malate dehydrogenase (oxaloacetatedecarboxylating), generating carbon dioxide and reductive potential. The further oxidation of pyruvate to acetyl-CoA is accomplished by pyruvate ferredoxin oxidoreductase, generating carbon dioxide and reduced ferredoxin (Thauer et al., 1977). The final reduction of acetyl-CoA with succinate to acetate occurs by succinyl-CoA:acetate CoA-transferase. Concurrently, two molecules of fumarate can be reduced to succinate by succinate dehydrogenase which was also annotated. Generation of ATP by coupling substrate-level phosphorylation is achieved by succinylCoA synthetase. DRI- $13^{\mathrm{T}}$ generates a proton motive force for ATP synthesis through a NADH ubiquinone-oxidoreductase (Nuo Complex 1) and membrane bound Ni-Fe hydrogenase4 (Marreiros et al., 2013; Schut et al., 2016; Yu et al., 2018). The $\mathrm{FPO}_{\mathrm{F}}$ complex allows versatility of energy conservation among anaerobes and is perhaps a recent adaptation to environments rich in sulfide and at an interface with oxygen (e.g., buoyancy), similar to water chemistry conditions found in monitoring well U-3cn\#5 (Schut et al., 2016). It is not known what molecule transports electrons to the hydrogenase$4 \mathrm{Ni}$-Fe complex. Interestingly, seven copies of electron transfer flavoprotein (EtfAB) and quinone oxidoreductase (FixC) were annotated within the genomes, suggesting capacity for high potential electron transfers in bifurcating energy conservation (Costas et al., 2017).

Secondary transporters dependent on substrate binding are ubiquitous in prokaryotes yet poorly characterized. Tripartite ATP-independent periplasmic (TRAP) transporters manage the passive transport of hydrocarbon molecules across the membrane for the cell to use as a source of carbon, electrons, and energy. Isolate DRI- $13^{\mathrm{T}}$ has fourteen TRAP 4TM/12TM genes present in its genome, six of which have fused transmembrane subsunits (Supplementary Table S2). TRAP transporters are proposed to be 'ancient' secondary transporters that are anchored in the membrane, taking advantage of sodium ion gradients to cotransport 4 carbon molecules from outside the cell wall into the cytoplasm (Rabus et al., 1999; Kelly and Thomas, 2001; Mulligan et al., 2011). The TRAP transporter's DctP subunit is seemingly specific to particular solutes (Fischer et al., 2015). DRI$13^{\mathrm{T}}$ 's almost exclusive utilization of the dicarboxylate molecule fumarate seems complimentary to the TRAP transport system. It has been demonstrated that the psychrophilic microorganism Psychrobacter arcticus 273-4, exhibited lower growth rates when its TRAP genes were genetically knocked out and afterward fed fumarate (Bakermans et al., 2009). DRI-13 ${ }^{\mathrm{T}}$ has 41 
TABLE 3 | Cellular fatty acid composition (\%) of strain DRI-13 ${ }^{\top}$ compared with its closest phylogenetic neighbors.

\begin{tabular}{|c|c|c|c|c|c|}
\hline Fatty Acid & DRI-13 ${ }^{\top}$ & $\mathrm{SI}^{\mathrm{T}} 1$ & $\mathrm{JT}^{\mathrm{T}} 2$ & LR7.2 ${ }^{\mathrm{T} 3}$ & Groll $^{\top} 4$ \\
\hline$C_{11: 0}$ & - & - & - & - & 1.9 \\
\hline Anteiso- $\mathrm{C}_{13: 0}$ & 2.1 & - & - & - & - \\
\hline $\mathrm{C}_{13: 0}$ & 1.3 & - & - & - & - \\
\hline iso- $C_{14: 0}$ & - & - & - & - & 1.6 \\
\hline $\mathrm{C}_{14: 0}$ & 11.6 & 3.2 & 26 & 5.8 & 2.6 \\
\hline iso- $\mathrm{C}_{15: 1} \mathrm{~F}$ & 2.9 & - & - & - & - \\
\hline *iso- $\mathrm{C}_{15: 1} \mathrm{H} / \mathrm{C}_{13: 0} 3 \mathrm{OH}$ & 1.2 & - & - & - & - \\
\hline iso- $\mathrm{C}_{15: 0}$ & 22.8 & 76.4 & 28.7 & 13.7 & 5.4 \\
\hline anteiso- $\mathrm{C}_{15: 0}$ & 2.5 & - & 9.2 & 18.9 & - \\
\hline $\mathrm{C}_{15: 1} \omega 8 \mathrm{C}$ & 2.1 & - & - & - & - \\
\hline$C_{15: 1} \omega 7 c$ & - & - & - & - & 2.7 \\
\hline$C_{15: 1} \omega 6 c$ & 1.5 & - & - & - & - \\
\hline $\mathrm{C}_{16: 0}$ alde & - & - & - & - & 2.2 \\
\hline$C_{15: 0}$ & 15 & - & - & 3.5 & - \\
\hline $\mathrm{C}_{15: 0} \mathrm{dma}$ & - & - & - & - & 1.7 \\
\hline iso- $\mathrm{C}_{16: 0}$ & - & - & - & 7.5 & - \\
\hline$C_{16: 1} \omega 7 c$ & - & - & - & - & 3.3 \\
\hline $\mathrm{C}_{16: 1} \omega 9 \mathrm{c}$ & 1.1 & - & - & 13.7 & 15.1 \\
\hline$C_{16: 1 \omega 11 C}$ & - & - & - & - & 3.6 \\
\hline${ }^{*} \mathrm{C}_{16: 1} \omega 7 c / \mathrm{C}_{16: 1} \omega 6 c$ & 5.8 & - & - & - & - \\
\hline$C_{16: 0}$ & 12 & 10.7 & 16.7 & 12.5 & 9.6 \\
\hline $\mathrm{C}_{16: 1} \omega 9 \mathrm{c} \mathrm{dma}$ & - & - & - & - & 4.6 \\
\hline $\mathrm{C}_{16: 0} \mathrm{dma}$ & - & - & - & - & 6.7 \\
\hline iso- $\mathrm{C}_{17: 1} \omega 7 \mathrm{C}$ & - & - & - & - & 4.8 \\
\hline iso- $C_{17: 1} \omega 9 c$ & 4.9 & 2.9 & - & - & - \\
\hline $\mathrm{C}_{17: 0}$ cyclo & - & - & - & - & 2.7 \\
\hline iso- $\mathrm{C}_{17: 0}$ & 1.8 & - & - & 5.7 & - \\
\hline anteiso- $\mathrm{C}_{17: 0}$ & - & - & - & 7.3 & - \\
\hline $\mathrm{C}_{17: 1 \omega 8 \mathrm{C}}$ & 1.5 & - & - & - & - \\
\hline$C_{17: 0}$ & 1 & - & - & - & - \\
\hline $\mathrm{C}_{18: 1} \omega 9 \mathrm{C}$ & - & - & - & 4.6 & 2 \\
\hline$C_{18: 1 \omega 11 C}$ & - & - & - & - & 3.3 \\
\hline$C_{18: 1 \omega 13 c}$ & - & - & - & - & 2.8 \\
\hline$C_{18: 0}$ & 3.6 & 6.7 & 7.1 & 4.2 & 5.6 \\
\hline $\mathrm{C}_{18: 1} \omega 11 \mathrm{c} d \mathrm{ma}$ & - & - & - & - & 1.5 \\
\hline
\end{tabular}

Only fatty acids that represent $\geq 1 \%$ of the total fatty acids of at least one strain are shown. *Summed features represent groups of two FAs not separated by MIDI system. alde, aldehyde; dma, dimethyl acetal; cyclo, cyclopropane. ${ }^{1}$ Pelotomaculum thermopropionicum strain SIT. ${ }^{2}$ Pelotomaculum terephthalicicum strain $J T^{T}$. ${ }^{3}$ Cryptanaerobacter phenolicus strain LR7.2T. ${ }^{4}$ Desulfotomaculum gibsoniae strain Groll ${ }^{T}$. Bold values indicate major FA that are $>10 \%$.

TRAP annotated transporter genes, compared with only three TRAP genes found in $P$. thermopropionicum. As for annotated genes, $10.4 \%$ of DRI- $13^{\mathrm{T}}$ genome fall under the category of transporter (390/3749 genes) as compared to $8.6 \%(259 / 3018)$ for $P$. thermopropionicum. Three of the fusion TRAP proteins in DRI-13 ${ }^{\mathrm{T}}$ genome (WP_034425417.1, WP_051965735.1, and WP_51966221.1) have 41-47\% amino acid identity to homologs in the deep subsurface bacterium $\mathrm{Ca}$. D. audaxviator (Chivian et al., 2008). The 'investment' of DRI-13 ${ }^{\mathrm{T}}$ genome with ATP independent secondary transporters potentially reveals a methodology of how subsurface microbes manage minimal energy metabolic activities in order to survive in oligotrophic environments. This is seemingly true for Alphaproteobacteria SAR11 that were sequenced from the Sargasso Sea, where TRAP transporters were found to be abundant (Morris et al., 2002; Mulligan et al., 2011).

Spore formation and germination genes were annotated in the genome as well (Brown et al., 1994; Browne et al., 2016). Isolate DRI-13 ${ }^{\mathrm{T}}$ appears to have 37 spore-related genes (Supplementary Table S2), as compared to microorganisms whose closest amino acid similarities to the GerA gene are Bacillus camelliae, which possesses 77 spore-related genes, and Desulfonispora thiosulfatigenes, which has 29 spore-annotated genes. Interestingly, the number of spore-related genes does not appear to differentiate microorganisms originating from surface and subsurface environments. For example, subsurface microorganisms such as Desulfotomaculum putei (26 sporerelated genes), Ca. D. audaxviator (8 spore-related genes), and Bacillus subterraneus (64 spore-related genes) can be compared to surface microorganisms such as Caldicellulosiruptor obsidiansis (11 spore-related genes), and Clostridium difficile BI1 (17 spore related genes).

\section{CONCLUSION}

The thermophilic, anaerobic, fumarate-respiring bacterium DRI$13^{\mathrm{T}}$ was successfully isolated from geothermal water from the Lower Carbonate Aquifer (LCA) of the Death Valley Regional Flow System (DVRFS) collected from fractures at 863 - 923 mbls. Physiological and molecular analysis of strain DRI- $13^{\mathrm{T}}$ revealed it to be a new species within a novel genus of the Family Peptococcaceae. Microbial community analysis via $16 \mathrm{~S}$ rRNA gene libraries of Archaea and Bacteria reveal a community consistent with other anoxic, rock-hosted subsurface aquifers. However, DRI- $13^{\mathrm{T}}$ was not present in these samples as a major community member. This study represents one of the first descriptions of indigenous life from the LCA of the DVRFS, and DRI- $13^{\mathrm{T}}$ is the first characterized microorganism from this deep subsurface extensional zone habitat. The apparent obligate reliance upon fumarate by this organism is relatively unusual and of uncertain significance in a deep biosphere context. Here we introduce DRI- $13^{\mathrm{T}}$ as a representative microorganism from the terrestrial deep biosphere and propose the name Thermoanaerosceptrum fracticalcis DRI- $13^{\mathrm{T}}$ gen. nov. sp. nov.

\section{Description of Thermoanaerosceptrum gen. nov.}

Thermoanaerosceptrum gen. nov. (Ther.mo.an.a.e.ro.scep'trum. Gr. adj. thermos, hot; Gr. prefix an-, not; Gr. n. aer air; Gr. neut. n. skeptron staff; N.L. neut. n. Thermoanaerosceptrum a hot anaerobic staff).

Cells are rod-shaped. Cell wall is Gram-positive type. Central endospores are observed. Thermophilic. Obligate anaerobic chemoorganoheterotroph. Fermentation end products are succinate and acetate. The major fatty acids (>10\%) were iso- $\mathrm{C}_{15: 0}, \mathrm{C}_{15: 0}, \mathrm{C}_{16: 0}$ and $\mathrm{C}_{14: 0}$.

The type species is Thermoanaerosceptrum fracticalcis. 


\section{Description of Thermoanaerosceptrum fracticalcis sp. nov.}

(frac.ti.cal'cis. L. part. adj. fractus, broken; L. n. calx, -cis, limestone; N.L. gen. n. fracticalcis, of broken limestone, referring to the origin of the type strain).

Cells are long, straight rods averaging $6 \mu \mathrm{m}$ long and $0.5 \mu \mathrm{m}$ wide, occurring singly. The cell wall is Grampositive type, with central endospores observed. Optimal growth temperature is $55^{\circ} \mathrm{C}$, with a maximum of $65^{\circ} \mathrm{C}$ and minimum of $35^{\circ} \mathrm{C}$. Optimal $\mathrm{pH}$ is 8.0 with a range of $7.0-8.5$. Obligate anaerobic chemoorganoheterotroph that utilizes fumarate as a sole carbon source and electron donor/acceptor for growth. Glucose, casamino acids, peptone, and yeast extract can be weakly utilized as electron/carbon donors. Fermentation end products are succinate and acetate. The estimated genome size of DRI-13 ${ }^{\mathrm{T}}$ is $3,649,665 \mathrm{bp}$, of which $87.3 \%$ are coding regions. The major fatty acids $(>10 \%)$ were iso- $\mathrm{C}_{15: 0}, \mathrm{C}_{15: 0}, \mathrm{C}_{16: 0}$ and $\mathrm{C}_{14: 0}$.

The type strain is DRI-13 ${ }^{\mathrm{T}}$ (DSM $100382^{\mathrm{T}}=$ ATCC TSD$12^{\mathrm{T}}$ ), which was isolated from a terrestrial deep biosphere aquifer located in the US Great Basin. The DNA G $+\mathrm{C}$ content of the type strain is $45.2 \mathrm{~mol} \%$.

\section{DATA AVAILABILITY STATEMENT}

The datasets generated for this study can be found in the JGI/IMG and NCBI.

\section{AUTHOR CONTRIBUTIONS}

SH-B designed the research project, organized the contributions of all other authors, conducted the experiments, collected the data, and led the writing effort. LS screened the first enrichments and initiated the isolation of microorganism. MZ, TO, and BL provided the geochemical data on U-3cn\#5. MC and PL performed and interpreted the lipid analysis. JG and IN performed HPLC and submitted the Illumina genome sequencing analysis. CR contributed to the experimental design and provided the hydrogeological and NNSS logistical expertise. DM secured the site access, collected the samples, secured the major funding, and co-wrote the manuscript.

\section{REFERENCES}

Amy, P., Haldeman, D., Ringelberg, D., Hall, D., and Russell, C. (1992). Comparison of identification systems for classification of bacteria isolated from water and endolithic habitats within the deep subsurface. Appl. Environ. Microbiol. 58, 3367-3373.

Baito, K., Imai, S., Matsushita, M., Otani, M., Sato, Y., and Kimura, H. (2015). Biogas production using anaerobic groundwater containing a subterranean microbial community associated with the accretionary prism. Microb. Biotechnol. 8, 837-845. doi: 10.1111/1751-7915.12179

Bakermans, C., Sloup, R. E., Zarka, D. G., Tiedje, J. M., and Thomashow, M. F. (2009). Development and use of genetic system to identify genes required for efficient low-temperature growth of Psychrobacter arcticus 273-4. Extremophiles 13, 21-30. doi: 10.1007/s00792-008-0193-3

\section{FUNDING}

This work was supported by the Department of Energy grant \#DE-PS02-09ER09-07, NASA Astrobiology Institute Cooperative Agreement NNA13AA92A, U.S. National Science Foundation grant DEB-1441717, startup funds for SH-B from Southern Illinois University Carbondale, and JGI Project 'Genome analyses of microbes integral to the cycling of sulfate and iron' IDs: Gs0014904 and Gp0046988. Work at Lawrence Livermore National Laboratory (LLNL) was supported by the Subsurface Biogeochemical Research Program of the U.S. Department of Energy's Office of Biological and Environmental Research (SCW1053).

\section{ACKNOWLEDGMENTS}

We thank Russ Shelton, David Finnegan, Jeff Wurtz, and others associated with the DOE UGTA program for logistical support and Bill Wilborn for site access. Special thanks to Brenna R. Hardtner from Henderson Foothill High School for providing the founding scientific name for DRI-13 ${ }^{\mathrm{T}}$, and to Craig Rosen from DRI's Green Power Project for facilitating the interaction with Southern Nevada High Schools. Thanks to Dr. John Shields from the University of Georgia for the SEM and TEM images, Dr. Bernhard Schink from the University of Konstanz for assisting with the proper Greek and Latin name description, Dr. Gerti Schut for the insightful discussions about hydrogenases, and Jenny C. Fisher for assisting with the collection of the U-3cn\#5 samples. We also thank Beverly Parker and the reviewers at DOE for the editorial advice and document clearance. Thanks to an undergraduate student David Lynn from the University of Nevada, Las Vegas, NV, United States for the seemingly endless centrifugation for genomic DNA. Work by MZ was prepared by LLNL under contract DE-AC52-07NA27344.

\section{SUPPLEMENTARY MATERIAL}

The Supplementary Material for this article can be found online at: https://www.frontiersin.org/articles/10.3389/fmicb. 2019.02224/full\#supplementary-material

Bangerter, R. M., and Giblin, M. O. (1998). Recompletion Report for BILBY. Nevada Environmental Restoration Project. Springfield, VA: National Technical Information Service.

Bastin, E. S., and Greer, F. E. (1930). Additional data on sulphate-reducing bacteria in soils and waters of Illinois oil fields. AAPG Bull. 14, 153-159.

Belcher, W. R., Bedinger, M. S., Back, J. T., and Sweetkind, D. S. (2009). Interbasin flow in the great basin with special reference to the southern funeral mountains and the source of furnace creek springs, Death Valley, California, U.S. J. Hydrol. 369, 30-43. doi: 10.1016/j.jhydrol.2009.02.048

Belcher, W. R., Sweetkind, D. S., and Elliott, P. E. (2002). Probability distributions of hydraulic conductivity for the hydrogeologic units of the Death Valley regional ground-water flow system, Nevada and California. Water Resour. Investig. Rep. 2:4212. 
Béranger, S. C., Sleep, B. E., Sherwood Lollar, B., and Brown, A. J. (2006). Isotopic fractionation of tetrachloroethene undergoing biodegradation supported by endogenous decay. J. Environ. Eng. 132, 725-735. doi: 10.1061/(asce)07339372(2006)132:7(725)

Boone, D. R., Liu, Y., Zhao, Z.-J., Balkwill, D. L., Drake, G. R., Stevens, T. O., et al. (1995). Bacillus infernus sp. nov., an Fe (III)-and Mn (IV)-reducing anaerobe from the deep terrestrial subsurface. Int. J. Syst. Bacteriol. 45, 441-448. doi: 10.1099/00207713-45-3-441

Borchardt, J. K. (1989). Chemicals Used in Oil-Field Operations. Houston, TX: Westhollow Research Center, Shell Development Company.

Bowen, S., Finnegan, D., Thompson, J., Miller, C., Baca, P., Olivas, L., et al. (2001). Nevada Test Site Radionuclide Inventory, 1951-1992. Los Alamos, NM: Los Alamos National Laboratory.

Brown, D. P., Ganova-Raeva, L., Green, B. D., Wilkinson, S. R., Young, M., and Youngman, P. (1994). Characterization of spo0A homologues in diverse Bacillus and Clostridium species identifies a probable DNA-binding domain. Mol. Microbiol. 14, 411-426. doi: 10.1111/j.1365-2958.1994.tb02 176.x

Browne, H. P., Forster, S. C., Anonye, B. O., Kumar, N., Neville, B. A., Stares, M. D., et al. (2016). Culturing of 'unculturable'human microbiota reveals novel taxa and extensive sporulation. Nature 533:543. doi: 10.1038/nature 17645

Bushmann, M., Nelson, S. T., Tingeya, D., and Eggett, D. (2010). Regional groundwater flow in structurally-complex extended terranes: an evaluation of the sources of discharge at Ash Meadows, Nevada. J. Hydrol. 386, 118-129. doi: 10.1016/j.jhydrol.2010.03.013

Chapelle, F. H., O’Neill, K., Bradley, P. M., Methé, B. A., Ciufo, S. A., Knobel, L. L., et al. (2002). A hydrogen-based subsurface microbial community dominated by methanogens. Nature 415, 312-315. doi: 10.1038/415312a

Chivian, D., Brodie, E. L., Alm, E. J., Culley, D. E., Dehal, P. S., Desantis, T. Z., et al. (2008). Environmental genomics reveals a single-species ecosystem deep within Earth. Science 322, 275-278. doi: 10.1126/science.1155495

Colwell, F. S., Onstott, T. C., Delwiche, M. E., Chandler, D., Fredrickson, J. K., Yao, Q. J., et al. (1997). Microorganisms from deep, high temperature sandstones: constraints on microbial colonization. FEMS Microbiol. Rev. 20, 425-435. doi: 10.1016/s0168-6445(97)00024-7

Costas, A. M. G., Poudel, S., Miller, A.-F., Schut, G. J., Ledbetter, R. N., Fixen, K. R., et al. (2017). Defining electron bifurcation in the electron transferring flavoprotein family. J. Bacteriol. 199:e0440-7. doi: 10.1128/JB.004 40-17

D'Agnese, F. A., Faunt, C. C., Turner, A. K., and Hill, M. C. (1997). Hydrogeologic Evaluation and Numerical Simulation of the Death Valley Regional GroundWater Flow System, Nevada and California. Denver, CO: U.S. Geological Survey.

Daumas, S., Cord-Ruwisch, R., and Garcia, J.-L. (1988). Desulfotomaculum geothermicum sp. nov., a thermophilic, fatty acid-degrading, sulfate-reducing bacterium isolated with $\mathrm{H} 2$ from geothermal ground water. Antonie Van Leeuwenhoek 54, 165-178. doi: 10.1007/bf00419203

Dorn, M., Andreesen, J., and Gottschalk, G. (1978). Fermentation of fumarate and L-malate by Clostridium formicoaceticum. J. Bacteriol. 133, 26-32.

Farnleitner, A. H., Wilhartitz, I., Ryzinska, G., Kirschner, A. K., Stadler, H., Burtscher, M. M., et al. (2005). Bacterial dynamics in spring water of alpine karst aquifers indicates the presence of stable autochthonous microbial endokarst communities. Environ. Microbiol. 7, 1248-1259. doi: 10.1111/j.1462-2920.2005. 00810.x

Fischer, M., Hopkins, A. P., Severi, E., Hawkhead, J., Bawdon, D., Watts, A. G., et al. (2015). Tripartite ATP-independent periplasmic (TRAP) transporters use an arginine-mediated selectivity filter for high affinity substrate binding. J. Biol. Chem. 290, 27113-27123. doi: 10.1074/jbc.M115.656603

Fredrickson, J. K., McKinley, J. P., Bjornstad, B. N., Long, P. E., Ringelberg, D. B., White, D. C., et al. (1997). Pore-size constraints on the activity and survival of subsurface bacteria in a late Cretaceous shale-sandstone sequence, northwestern New Mexico. Geomicrobiol. J. 14, 183-202. doi: 10.1080/ 01490459709378043

Garber, M. S., and Johnson, R. H. (1967). A Summary of Lithologic Data, Aquifer Tests, and Contruction of Hydraulic Test Well U-3cn\#5,
Nevada Test Site. Denver, CO: United States Department of the Interior, Geological Survey.

Gihring, T., Moser, D., Lin, L.-H., Davidson, M., Onstott, T., Morgan, L., et al. (2006). The distribution of microbial taxa in the subsurface water of the Kalahari Shield, South Africa. Geomicrobiol. J. 23, 415-430. doi: 10.1080/ 01490450600875696

Glöckner, F. O., Yilmaz, P., Quast, C., Gerken, J., Beccati, A., Ciuprina, A., et al. (2017). 25 years of serving the community with ribosomal RNA gene reference databases and tools. J. Biotechnol. 261, 169-176. doi: 10.1016/j.jbiotec.2017.06. 1198

Gold, T. (1992). The deep, hot biosphere. Proc. Natl. Acad. Sci. U.S.A. 89, 6045-6049.

Grayson, D. K. (2011). The Great Basin: A Natural Prehistory. Berkeley, CA: University of California Press.

Haldeman, D., and Amy, P. (1993). Bacterial heterogeneity in deep subsurface tunnels at Rainier Mesa, Nevada Test Site. Microb. Ecol. 25, 183-194. doi: 10.1007/BF00177194

Haldeman, D. L., Amy, P. S., Ringelberg, D., and White, D. C. (1993). Characterization of the microbiology within a $21 \mathrm{~m} 3$ section of rock from the deep subsurface. Microb. Ecol. 26, 145-159. doi: 10.1007/BF0017 7049

Hohnstock-Ashe, A., Plummer, S., Yager, R., Baveye, P., and Madsen, E. (2001). Further biogeochemical characterization of a trichloroethene-contaminated fractured dolomite aquifer: electron source and microbial communities involved in reductive dechlorination. Environ. Sci. Technol. 35, 4449-4456. doi: 10.1021/es0110067

Imachi, H., Sakai, S., Ohashi, A., Harada, H., Hanada, S., Kamagata, Y., et al. (2007). Pelotomaculum propionicicum sp nov., an anaerobic, mesophilic, obligately syntrophic propionate-oxidizing bacterium. Int. J. Syst. Evol. Microbiol. 57, 1487-1492. doi: 10.1099/ijs.0.64925-0

Imachi, H., Sekiguchi, Y., Kamagata, Y., Hanada, S., Ohashi, A., and Harada, H. (2002). Pelotomaculum thermopropionicum gen. nov., sp nov., an anaerobic, thermophilic, syntrophic propionate-oxidizing bacterium. Int. J. Syst. Evol. Microbiol. 52, 1729-1735. doi: 10.1099/ijs.0.02212-0

Jorgensen, B. B. (2012). Shrinking majority of the deep biosphere. Proc. Natl. Acad. Sci. U.S.A. 109, 15976-15977. doi: 10.1073/pnas.121363 9109

Juteau, P., Côté, V., Duckett, M.-F., Beaudet, R., Lépine, F., Villemur, R., et al. (2005). Cryptanaerobacter phenolicus gen. nov., sp. nov., an anaerobe that transforms phenol into benzoate via 4-hydroxybenzoate. Int. J. Syst. Evol. Microbiol. 55, 245-250. doi: 10.1099/ijs.0.02914-0

Kampfer, P., and Kroppenstedt, R. M. (1996). Numerical analysis of fatty acid patterns of coryneform bacteria and related taxa. Can. J. Microbiol. 42, 989-1005. doi: 10.1139/m96-128

Kang, M., and Jackson, R. B. (2016). Salinity of deep groundwater in California: water quantity, quality, and protection. Proc. Natl. Acad. Sci. U.S.A. 113, 7768-7773. doi: 10.1073/pnas.1600400113

Kelly, D. J., and Thomas, G. H. (2001). The tripartite ATP-independent periplasmic (TRAP) transporters of bacteria and archaea. FEMS Microbiol. Rev. 25, 405-424. doi: 10.1016/s0168-6445(01)00061-4

Kieft, T. L., Kovacik, W., Ringelberg, D. B., White, D. C., Haldeman, D. L., Amy, P. S., et al. (1997). Factors limiting microbial growth and activity at a proposed high-level nuclear repository, yucca mountain, nevada. Appl. Environ. Microbiol. 63, 3128-3133.

Kjeldsen, K. U., Kjellerup, B. V., Egli, K., Frolund, B., Nielsen, P. H., and Ingvorsen, K. (2007). Phylogenetic and functional diversity of bacteria in biofilms from metal surfaces of an alkaline district heating system. FEMS Microbiol. Ecol. 61, 384-397. doi: 10.1111/j.1574-6941.2006.00255.x

Kotelnikova, S., and Pedersen, K. (1997). Evidence for methanogenic Archaea and homoacetogenic Bacteria in deep granitic rock aquifers. FEMS Microbiol. Rev. 20, 339-349. doi: 10.1016/s0168-6445(97)00016-8

Krumholz, L. R., McKinley, J. P., Ulrich, G. A., and Suflita, J. M. (1997). Confined subsurface microbial communities in Cretaceous rock. Nature 386, 64-66. doi: $10.1038 / 386064 \mathrm{a} 0$

Kuever, J., Rainey, F. A., and Hippe, H. (1999). Description of Desulfotomaculum sp Groll as Desulfotomaculum gibsoniae sp nov. Int. J. Syst. Bacteriol. 49, 1801-1808. doi: 10.1099/00207713-49-4-1801 
Lane, D. J. (1991). "16S/23S rRNA Sequencing," in Nucleic Acid Techniques in Bacterial Systematics, eds E. Stackebrandt, and M. Goodfellow, (Hoboken, NJ: John Wiley and Sons).

Lau, M. C., Cameron, C., Magnabosco, C., Brown, C. T., Schilkey, F., Grim, S., et al. (2014). Phylogeny and phylogeography of functional genes shared among seven terrestrial subsurface metagenomes reveal $\mathrm{N}$-cycling and microbial evolutionary relationships. Front. Microbiol. 5:531. doi: 10.3389/fmicb.2014. 00531

Lehman, R. M., Roberto, F. F., Earley, D., Bruhn, D. F., Brink, S. E., O’Connell, S. P., et al. (2001). Attached and unattached bacterial communities in a 120-meter corehole in an acidic, crystalline rock aquifer. Appl. Environ. Microbiol. 67, 2095-2106. doi: 10.1128/aem.67.5.2095-2106. 2001

Lin, L.-H., Hall, J., Onstott, T., Gihring, T., Lollar, B. S., Boice, E., et al. (2006). Planktonic microbial communities associated with fracture-derived groundwater in a deep gold mine of South Africa. Geomicrobiol. J. 23, 475-497. doi: 10.1080/01490450600875829

Magnabosco, C., Lin, L.-H., Dong, H., Bomberg, M., Ghiorse, W., Stan-Lotter, H., et al. (2018). The biomass and biodiversity of the continental subsurface. Nat. Geosci. 11, 707-717. doi: 10.1038/s41561-018-0221-6

Markowitz, V. M., Chen, I. M., Palaniappan, K., Chu, K., Szeto, E., Pillay, M., et al. (2014). IMG 4 version of the integrated microbial genomes comparative analysis system. Nucleic Acids Res. 42, D560-D567. doi: 10.1093/nar/ gkt963

Marreiros, B. C., Batista, A. P., Duarte, A. M., and Pereira, M. M. (2013). A missing link between complex I and group 4 membrane-bound [NiFe] hydrogenases. Biochim. Biophys. Acta 1827, 198-209. doi: 10.1016/j.bbabio.2012. 09.012

McMahon, S., and Parnell, J. (2014). Weighing the deep continental biosphere. FEMS Microbiol. Ecol. 87, 113-120. doi: 10.1111/1574-6941. 12196

Miller, T. L., and Wolin, M. J. (1974). A serum bottle modification of the Hungate technique for cultivating obligate anaerobes. Appl. Microbiol. 27, 985-987.

Morris, R. M., Rappé, M. S., Connon, S. A., Vergin, K. L., Siebold, W. A., Carlson, C. A., et al. (2002). SAR11 clade dominates ocean surface bacterioplankton communities. Nature 420, 806-810. doi: 10.1038/nature 01240

Moser, D. P., Gihring, T. M., Brockman, F. J., Fredrickson, J. K., Balkwill, D. L., Dollhopf, M. E., et al. (2005). Desulfotomaculum and Methanobacterium spp. dominate a 4 - to 5-kilometer-deep fault. Appl. Environ. Microbiol. 71, 8773-8783.

Mulligan, C., Fischer, M., and Thomas, G. H. (2011). Tripartite ATP-independent periplasmic (TRAP) transporters in bacteria and archaea. FEMS Microbiol. Rev. 35, 68-86. doi: 10.1111/j.1574-6976.2010.00236.x

Nielsen, M. B., Kjeldsen, K. U., and Ingvorsen, K. (2006). Desulfitibacter alkalitolerans gen. nov., sp nov., an anaerobic, alkalitolerant, sulfite-reducing bacterium isolated from a district heating plant. Int. J. Syst. Evol. Microbiol. 56, 2831-2836. doi: 10.1099/ijs.0.64356-0

Nilsen, R. K., Torsvik, T., and Lien, T. (1996). Desulfotomaculum thermocisternum sp. nov., a sulfate reducer isolated from a hot North Sea oil reservoir. Int. J. Syst. Bacteriol. 46, 397-402. doi: 10.1099/00207713-462-397

Nisman, B. (1954). The stickland reaction. Bacteriol. Rev. 18:16.

Osburn, M. R., LaRowe, D. E., Momper, L. M., and Amend, J. P. (2014). Chemolithotrophy in the continental deep subsurface: sanford underground research facility (SURF), USA. Front. Microbiol. 5:610. doi: 10.3389/fmicb.2014. 00610

Park, J., Sanford, R. A., and Bethke, C. M. (2009). Microbial activity and chemical weathering in the Middendorf aquifer, South Carolina. Chem. Geol. 258, 232241. doi: 10.1016/j.chemgeo.2008.10.011

Pedersen, K., and Ekendahl, S. (1990). Distribution and activity of bacteria in deep granitic groundwaters of southeastern Sweden. Microb. Ecol. 20, 37-52. doi: 10.1007/BF02543865

Pfiffner, S. M., Cantu, J. M., Smithgall, A., Peacock, A. D., White, D. C., Moser, D. P., et al. (2006). Deep subsurface microbial biomass and community structure in Witwatersrand Basin mines. Geomicrobiol. J. 23, 431-442. doi: 10.1080/ 01490450600875712
Puspita, I. D., Kamagata, Y., Tanaka, M., Asano, K., and Nakatsu, C. H. (2012). Are uncultivated bacteria really uncultivable? Microbes Environ. 27, 356-366. doi: 10.1264/jsme2.me12092

Qiu, Y.-L., Sekiguchi, Y., Hanada, S., Imachi, H., Tseng, I.-C., Cheng, S.-S., et al. (2006). Pelotomaculum terephthalicum sp. nov. and Pelotomaculum isophthalicum sp. nov.: two anaerobic bacteria that degrade phthalate isomers in syntrophic association with hydrogenotrophic methanogens. Arch. Microbiol. 185, 172-182. doi: 10.1007/s00203-005-0081-5

Rabus, R., Jack, D. L., Kelly, D. J., and Saier, M. H. Jr. (1999). TRAP transporters: an ancient family of extracytoplasmic solute-receptor-dependent secondary active transporters. Microbiology 145, 3431-3445. doi: 10.1099/00221287-145-123431

Ravot, G., Magot, M., Fardeau, M.-L., Patel, B., Prensier, G., Egan, A., et al. (1995). Thermotoga elfii sp. nov., a novel thermophilic bacterium from an African oilproducing well. Int. J. Syst. Bacteriol. 45, 308-314. doi: 10.1099/00207713-452-308

Sackett, J. D. (2018). Prokaryotic Diversity and Aqueous Geochemistry of Subsurface Environments of the Death Valley Regional Flow System. Ph.D. thesis, University of Nevada Las Vegas, Nevada.

Sambrook, J., and Russell, D. W. (2001). Molecular Cloning: A Laboratory Manual. Cold Spring Harbor, NY: Cold Spring Harbor Laboratory Press.

Sasser, M. (2001). MIDI Technical Note \#101: Bacterial Identification by Gas Chromatographic Analysis of Fatty Acids Methyl Esters (GC-FAME). Newark, DE: MIDI, Inc.

Schut, G. J., Zadvornyy, O., Wu, C.-H., Peters, J. W., Boyd, E. S., and Adams, M. W. (2016). The role of geochemistry and energetics in the evolution of modern respiratory complexes from a proton-reducing ancestor. Biochim. Biophys. Acta 1857, 958-970. doi: 10.1016/j.bbabio.2016.01.010

Stevens, T. O., and McKinley, J. P. (1995). Lithoautotrophic microbial ecosystems in deep basalt aquifers. Science 270, 450-455. doi: 10.1038/s41467-01701288-8

Takai, K., Moser, D. P., DeFlaun, M., Onstott, T. C., and Fredrickson, J. K. (2001). Archaeal diversity in waters from deep South African gold mines. Appl. Environ. Microbiol. 67, 5750-5760. doi: 10.1128/aem.67.21.5750-5760. 2001

Tamura, K., Peterson, D., Peterson, N., Stecher, G., Nei, M., and Kumar, S. (2011). MEGA5: molecular evolutionary genetics analysis using maximum likelihood, evolutionary distance, and maximum parsimony methods. Mol. Biol. Evol. 28, 2731-2739. doi: 10.1093/molbev/msr121

Thauer, R. K., Jungermann, K., and Decker, K. (1977). Energy conservation in chemotrophic anaerobic bacteria. Bacteriol. Rev. 41, $100-180$.

Thomas, J. M., Moser, D. P., Fisher, J. C., Reihle, J., Wheatley, A., Hershey, R. L., et al. (2013). Using water chemistry, isotopes and microbiology to evaluate groundwater sources, flow paths and geochemical reactions in the death valley flow system, USA. Proc. Earth Planet. Sci. 7, 842-845. doi: 10.1016/j.proeps. 2013.03.033

Thompson, J. (1999). Laboratory and Field Studies Related to Radionuclide Migration at the Nevada Test Site. Los Alamos, MN: Los Alamos National Laboratory.

Weisburg, W. G., Barns, S. M., Pelletier, D. A., and Lane, D. J. (1991). 16s ribosomal DNA amplification for phylogenetic study. J. Bacteriol. 173, 697-703. doi: 10.1128/jb.173.2.697-703.1991

Whitman, W. B., Coleman, D. C., and Wiebe, W. J. (1998). Prokaryotes: the unseen majority. Proc. Natl. Acad. Sci. U.S.A. 95, 6578-6583. doi: 10.1073/pnas.95.12. 6578

Winograd, I. J., Fridrich, C. J., Sweetkind, D., Belcher, W. R., and Thomas, J. M. (2005). Comment on testing the interbasin flow hypothesis at Death Valley, California. EOS Trans. Am. Geophys. Union 86, 295-296.

Winograd, I. J., and Pearson, F. (1976). Major carbon 14 anomaly in a regional carbonate aquifer: possible evidence for megascale channeling, south central Great Basin. Water Resour. Res. 12, 1125-1143. doi: 10.1029/wr012i006p01125

Winograd, I. J., and Thordarson, W. (1975). Hydrogeologic and Hydrochemical Framework, South-Central Great Basin, Nevada-California, With Special Reference to the Nevada Test Site, USGS Professional Paper 712-C.

Yarza, P., Yilmaz, P., Pruesse, E., Glockner, F. O., Ludwig, W., Schleifer, K. H., et al. (2014). Uniting the classification of cultured and uncultured bacteria 
and archaea using 16S rRNA gene sequences. Nat. Rev. Microbiol. 12, 635-645. doi: $10.1038 /$ nrmicro3330

Ye, M., Pohlmann, K. F., and Chapman, J. B. (2008). Expert elicitation of recharge model probabilities for the Death Valley regional flow system. J. Hydrol. 354, 102-115. doi: 10.1016/j.jhydrol.2008.03.001

Yu, H., Wu, C.-H., Schut, G. J., Haja, D. K., Zhao, G., Peters, J. W., et al. (2018). Structure of an ancient respiratory system. Cell 173, 1636-1649.e16. doi: $10.1016 /$ j.cell.2018.03.071

Zavarin, M. (2014). Yields and Cavity Radii of Underground Nuclear Tests with Specified Yields Reported in DOE/NV-209-REV 15 (2000). Livermore, CA: Lawrence Livermore National Laboratory.
Conflict of Interest: The authors declare that the research was conducted in the absence of any commercial or financial relationships that could be construed as a potential conflict of interest.

Copyright $\odot 2019$ Hamilton-Brehm, Stewart, Zavarin, Caldwell, Lawson, Onstott, Grzymski, Neveux, Lollar, Russell and Moser. This is an open-access article distributed under the terms of the Creative Commons Attribution License (CC BY). The use, distribution or reproduction in other forums is permitted, provided the original author(s) and the copyright owner(s) are credited and that the original publication in this journal is cited, in accordance with accepted academic practice. No use, distribution or reproduction is permitted which does not comply with these terms. 